\title{
مدن المعرفة: دراسة حالة حاضرة الدمام - المملكة العربية السعودية
}

\section{فائز سعد الشهري}

قسم التخطبط الحضري والإقلبيس، كلية العدارة والتخطبط، جامعة الدمام، ص.ب. 2397، الدمام 31451، المدلكة العربية السعودية fshihri@ud.edu.sa

$$
\text { (قدم للنشر في 2012/8/9، قبل للنشر في 2013/8/1) }
$$

المستخلص. يهدف البحث إلى تقديم دراسة لما ينبغي أن تكون عليه مدن المعرفـة وتحديد جوانب ومفردات تخطيطها. فالمدينـة الحاليـة

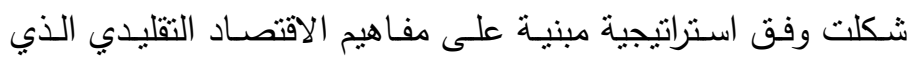

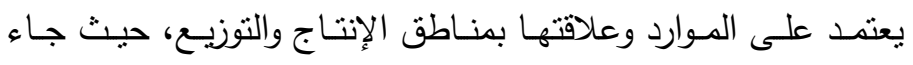
مخطط المدينة موزعًا إلى مناطق من الأنشطة الاقتصادية التي تعتمد الإناجد

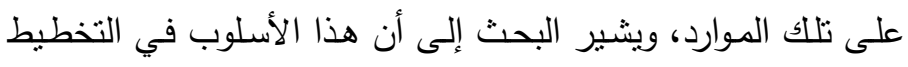

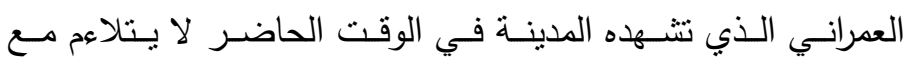
منطلبات مدينة الغد التي تعتمد على قاعدة اقتصـادية معرفية تشكل

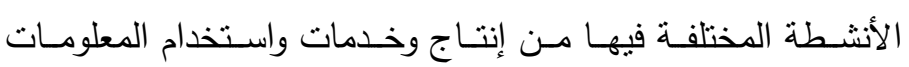

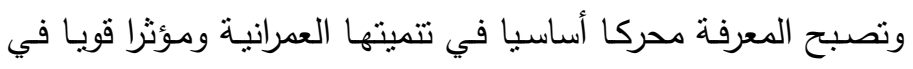
الأساليب والأطر التي تقوم عليها وظائفها العمرانية وأساليب معيشية لمئية

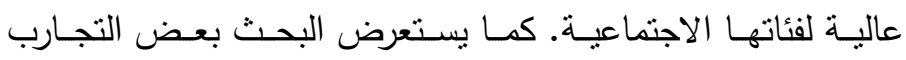

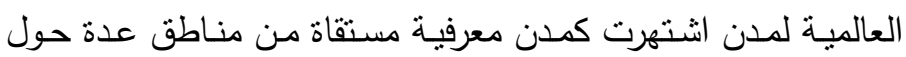


العـالم، مستخلصـا الدروس مـن تجـارب تلك المدن، ويختنم البحث

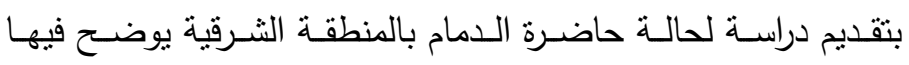
المقومات والإمكانيات والفرص لجعل حاضرة الدمام منارة معرفية. الكلمات الدفتاحية: التخطيط العمراني، مدن المعرفة، المنطقة الثرقية، حاضرة الامام، المملكة العربية السعودية.

\section{1}

ركزت العديد من أعمال البحث العلمي على اقتصاد المعرفة الناشئة، حيث شبكات التواصـل الاجتمـاعي وتكنولوجيـا المعلومـات والاتصـالات في تزايد مستمر • ومـع ذلك، أجريت أبحاث قليلة للتعامل مع أساليب ومناهج التخطيط العمراني للمدينة التي تقوم على هذا النوع من المأوى لمجتمع المعرفة والأنشطة المرتبطة بها. يثكل الاقتصاد المعرفي صلب هذه المخططات حيث يتم التركيز فيها على إنتـاج وتوزيــع المعرفـة وتطبيقهـا مـع مراعـاة قضــايا البيــة المسـتـامة والعدالـة الاجتماعيـة وتكـافؤ الفـرص الاقتصــادية. كمــا يقـدم مفاهيمًا وأفكـارًا معاصــرة كمخططات منـاطق معرفيـة ومنظومسة شبكات ، واتصسالات تسـل عمليات تبـادل المعرفـة والمعلومـات واسـتخداماتها مـع مراعـاة التتميــة المسـتـامة والتوجهـات

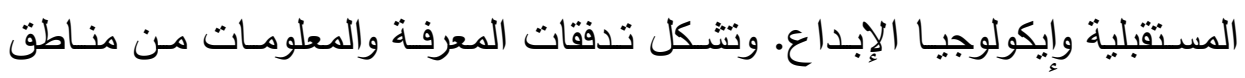
المصـدر إلـى منـاطق الحاجـة والفـرص عصـب هـذه المخططـات الاسـتراتيجية المعرفية بالإضافة إلى العديد من مبادئ المدن المعرفية كتجارة المعرفة [1] ويقوم البحث على استكثاف الجوانب والمفردات التخطيطية للمدينة القائمـة على المعرفـة. ويراجـع كيفيـة نهـوض اقتصـاد المعرفـة لتغييـر البيئـة الحضـرية والصـورة البصـرية للمـدن التـي تفرض نفسـها في شـكل عمرانسي حديث يلائم احتياجات الأنشطة الاقتصـادية الناشئة. يركز الجزء النظري بالبحث على كيفية 
الانتقال من الاقتصـاد التقليدي إلى الاقتصـاد المعاصر القائم على المعرفة. بعد ذلك يراجع ماهيبة الثبكة العالميـة للتواصل الناثئة عبر المدن التي تعمل على التى صـياغة الصـورة البصـرية للعمـران في المستقبل. ويقوم بدراسـة الملامـح الجديدة لمدينة المعرفة التي ينبغي أن تطرح مـع مطالب الأنشطة المتزايدة المعتمدة على شبكات تدفق المعلومـات والمعرفة. إن مقتضيات التبـادل الاقتصـادي في المدينـة يتطلـب جذب والاحتفـاظ بالجهـات الفاعلـة الرئيسية في هـذا الاقتصـاد الواعـد الصاعد، والعاملين في مجال المعرفة. أي أن نكون مدينة المعرفة وظيفيا فعالة في حين تقدم حياة عمرانية حيوية وجذابة وذات جودة عالية. لهذا فيان الورقة البحثيـة تراجع وتتاقش الأجزاء التاليـة: القضـايا المتعلقة بالتخطيط والتصميم الحضري لمدينة المعرفة. ويؤكد مخططو المدن أن بضعوا في الاعتبـار حقيقة تصميم المدينة الجديدة التي ينبغي أن تتظر في فكرة الوصسولية وليس القرب/الدمج العدراني والتواصل، وكذللك مناطق شبكات الابتكار المعرفية بدلا من مناطق استخدام الأراضي التقليدية، وتذفق السلع والمعلومات والناس عبر الثبكة وليس المستخدمين وحركة المنتجات من منطقة إلى أخرى. وهناك مجموعة واسعة جديدة من المفاهيم الناشئة التي يمكن التعامل معها وإدراجها في الجانب النظري لتخطيط وتصميم مدينة المعرفة.

ويتم عرض بعض النماذج من المدن العالمية التي توصف بأنها جزء من عصر المعرفة وكذلك شرحًا للمنهج المعتمد لكل مدينـة وأخذ الدروس المستفادة. كما يركز الجزء التطبيقي على استعراض الأوضاع الراهنة، وأهم القضايا والتحديات التي تواجه جهود التوجه نحو الاقتصـاد القائم على المعرفة على المستوي الوطني،

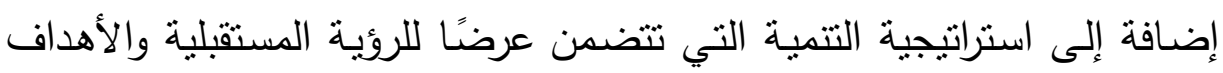
العامة، والسياسـات، والأهداف المحددة التي تتبناها خطة التتمية التاسعة في هذا الخصوص، ويناقش الرؤى المستقبلية التي طرحتها المخططات الهيكلية والمحلية 
لحاضرة الدمام لحصر أهم عناصر التتمية القائمة على المعرفة حتى يمكن نقل الحاضرة إلى حاضرة معرفية تتافسية عالمية ويختم البحث بالنتائج والتوصيات.

1.1

تكمن أهمية الدراسـة في الربط بين الاقتصـاد المعرفي وإسقاطاته المكانية

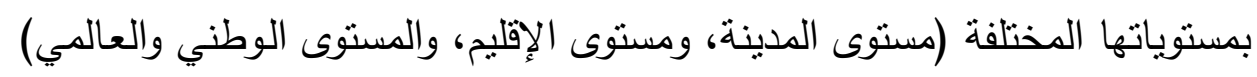

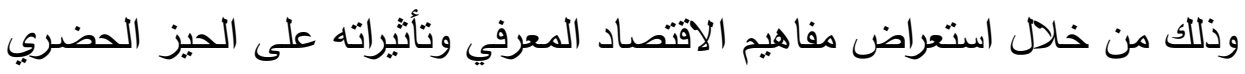

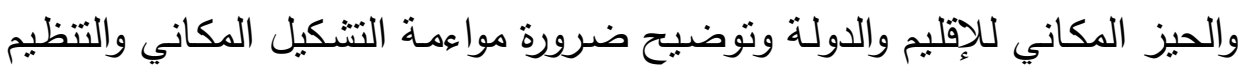
الجغرافي مع منطلبات هذا النمط من النشاط الاقتصادي المعرفي. 1.2

\section{يسعى البحث إلى تحقيق عدة أهداف منها:}

توضيح العلاقة بين الاقتصاد المعرفي ومدينة المعرفة باعتبارها الوعاء

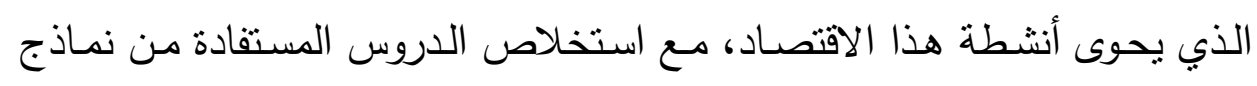
وتجارب مدن معرفة عالمية.

عرض التحارب والمفاهيم المستحدثة لمناطق وأماكن المعرفة.

عرض الأوضاع الراهنة، وأهم القضايا والتحديات التي تواجه جهود التوجه

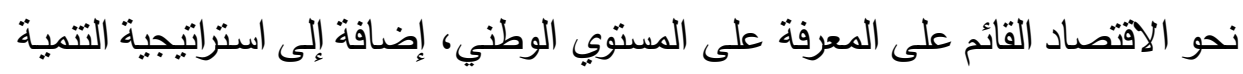

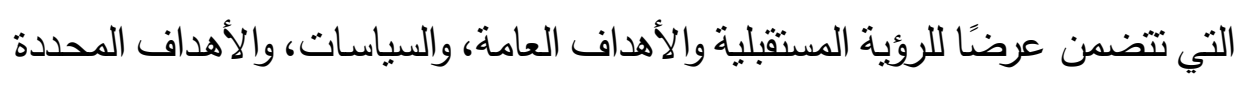
التي تتبناها خطة التتمية التاسعة في هذا الخصوص. • مناقثــة وتحليل الـرؤى المستقبلية التـي طرحتهـا المخططـات الهيكليـة

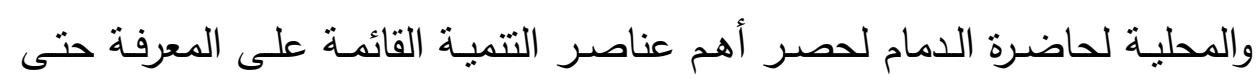
يمكن نقل الحاضرة إلى حاضرة معرفية تتافسية عالمية. 


\section{3 منهجية البحث}

يقـوم البحـث على دراسـة نظريـة لدفـاهيم ومبـادئ الاقتصــاد المعرفي وانعكاساته على السياسات والاستراتيجيات التخطيطية للتنكيل العمراني والوظيفي لمدينة المعرفة. كما يتم عرض دراسة نقدية لتجارب مدن قائمة على المعرفة في

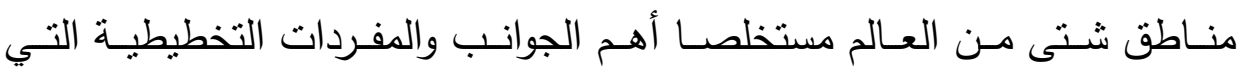

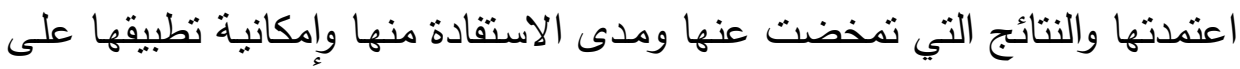

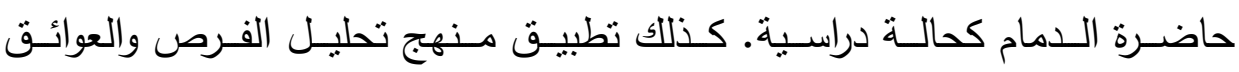
والمحددات والمخاطر SWOT analysis لهذا النسيج بهدف التعرف على الفرص

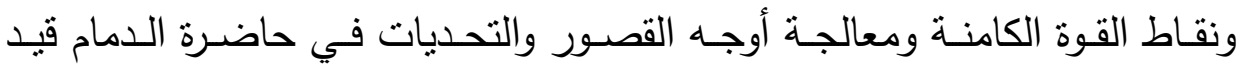

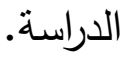

\section{2. مدن المعرفة والمدينة الافتراضية}

ترجع نشأة المدينة الي إيجاد مناطق لديها القدرة على توفير فرص التواصل والتفاعل بين السكان. لتحقيق هذا الهدف، اتخذت مدينة مـا قبل الصناعة شكل

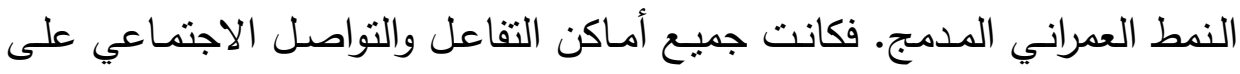

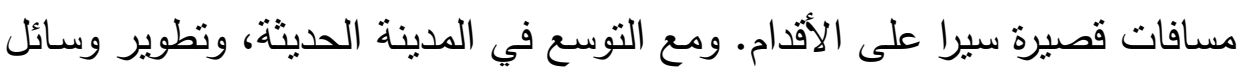
النقل وتكنولوجيا الاتصـالات السـلكية واللاسلكية، قدمت وسـائل جديدة لتفاعل التل وتبادل العلاقات بين السكان والتي قامت للتغلب على مشكلة ضيق المساحة

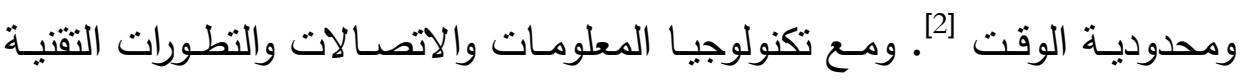
العالية، لم تعد تقتصر الاتصالات وتواصل السكان إلى حدود المدينة فقط ولكن

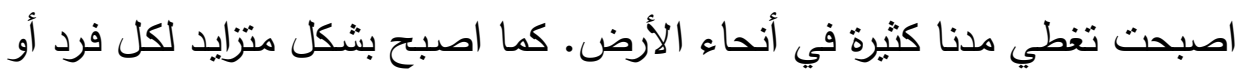

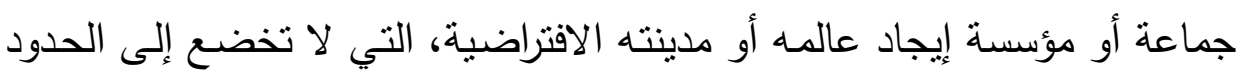

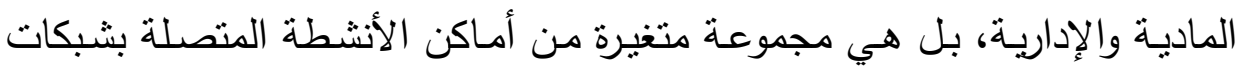

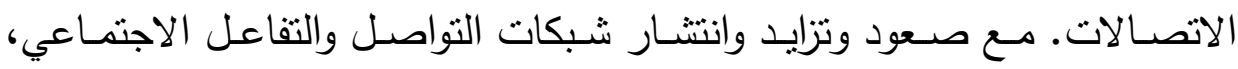


أصبح بإمكان الناس والمؤسسات في جميع أنحاء العالم التصفح خـلال شبكات الإنترنت المرتبطة بالمدن.

ينظر الآن إلى المدينة الافتراضية من جانب المستخدمين على أنها فراغ

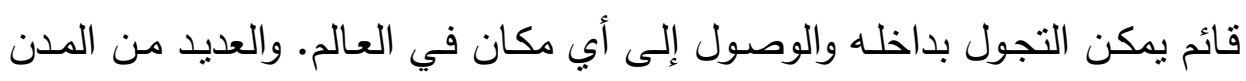

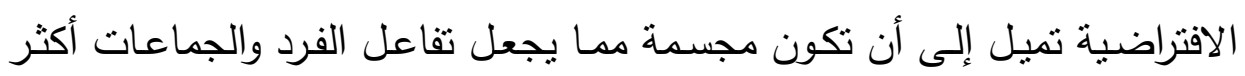

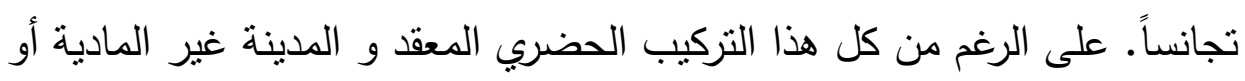
الافتراضية، ولا تزال تلعب المناطق الحضرية دورا هاما في خدمة مراكز التفاعل

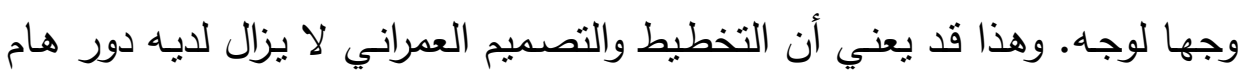

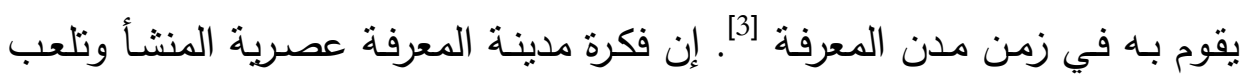

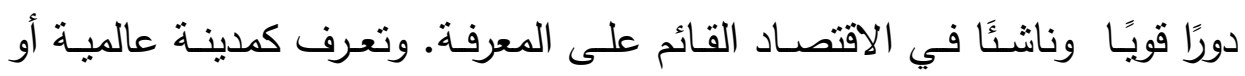

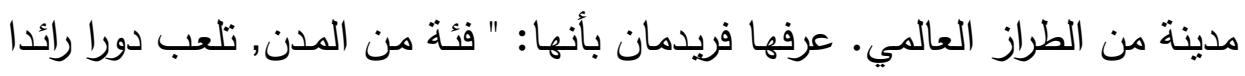

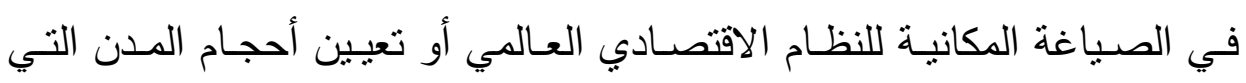

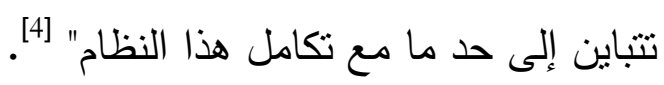

أنشئت مدينة المعرفة لاجتذاب الأشخاص الموهوبين المبتكرين مع انتشار

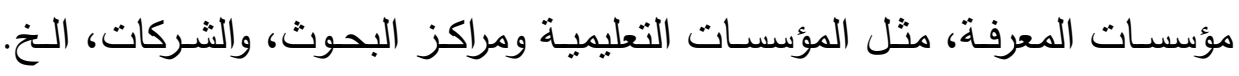

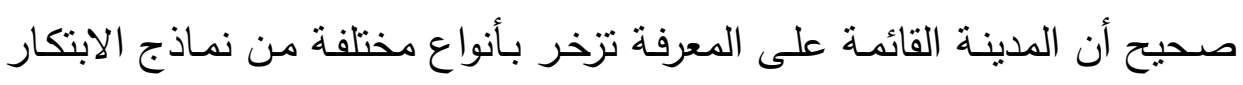

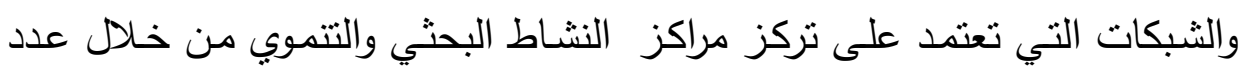
ونوعية المنظمات والمؤسسات التي تتأصل فيها، واختصاص تولئ العاملين في مجال

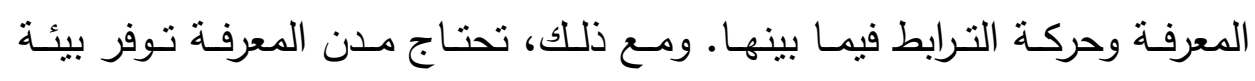

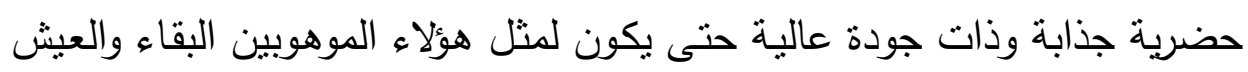

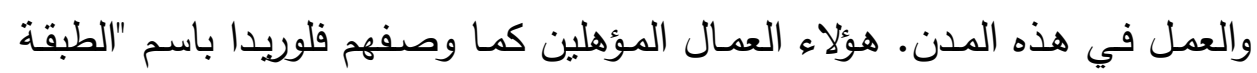
المبدعة" التي تضم العاملين في شؤون تكنولوجيا المعلومات والاتصـالات والعمارة والهندسة والعلوم والتعليم والفنون والتصميم، وكذلك في الرعاية الصحية والإدارة 
والتمويل والقانونية و التسويق. إن تقنيات المعلومات تعني تقارب وسائل الإعلام والاتصالات وشبكات الحاسوب وبالتالي تكون البنية التحنية الأساسية التي يقوم عليها التحول نحو شبكات الاتصال منرابطة بشكل مكثق في المناطق الحضرية. تطوير وتتمية مدينة المعرفة يتحقق على ثلاثة محاور رئيسية: الاقتصادية

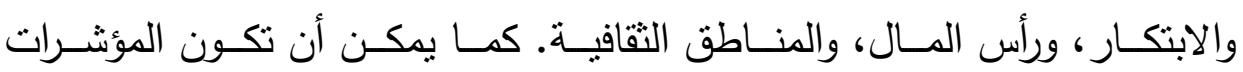

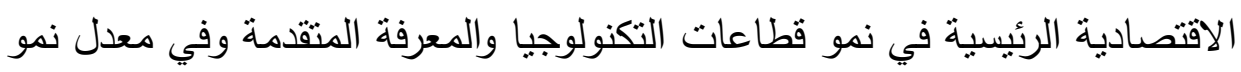

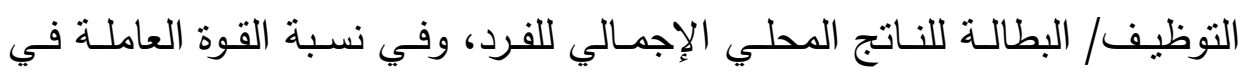

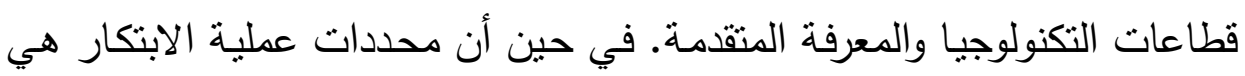

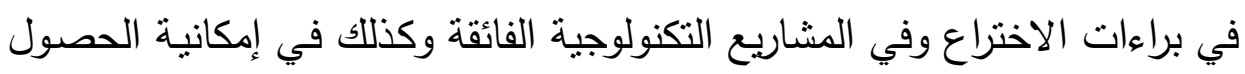

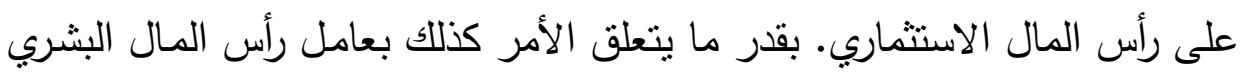

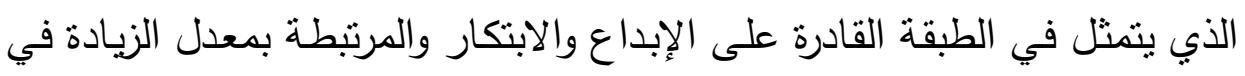

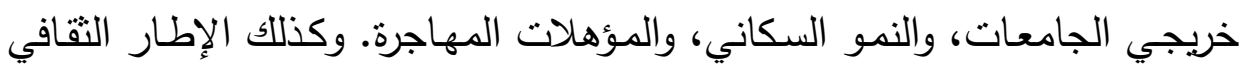
والاجتماعي للسكان إلى جانب درجة من الانفتاح على التنوع الثقافي والاجتماعي.

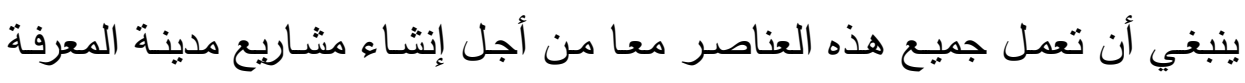

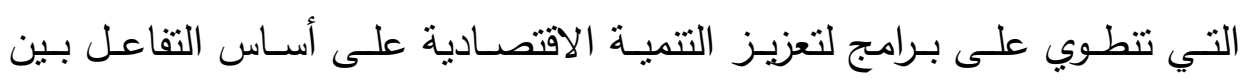

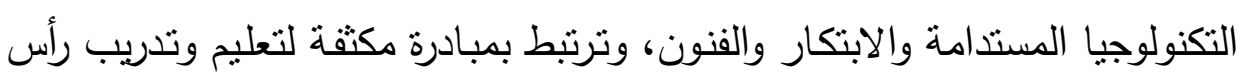

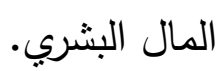

\section{3. النمط التخطيطي المعاصر لمدن المعرفة}

يختلف شكل وهيكل مدينة المعرفة من جوانب عديدة عن الددينة الحديثة أو

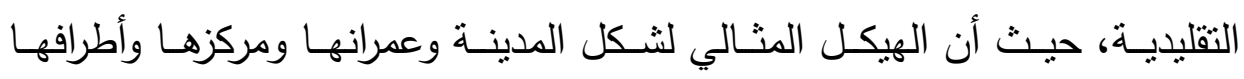
وحدودها وضـواحيها، وللحضـر والريف. يتعـارض مـع فكرة تعدد المراكز وفكرة

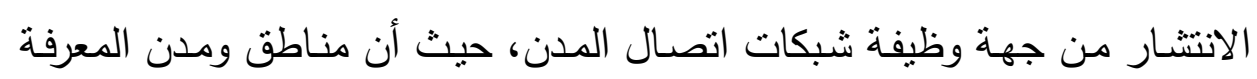
تمنالك سمانًا خاصة. 


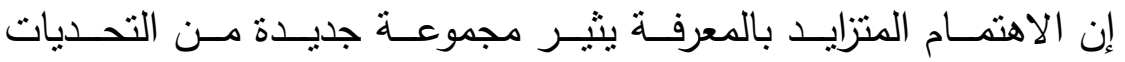

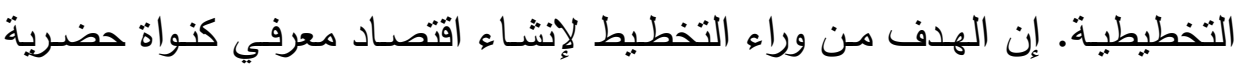
قويـة تعتبر نقطة ارتكاز قوية للمحافظة على الددن والتجمعات النشطة البعيدة

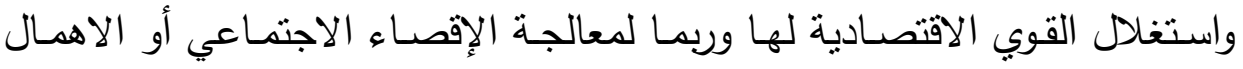

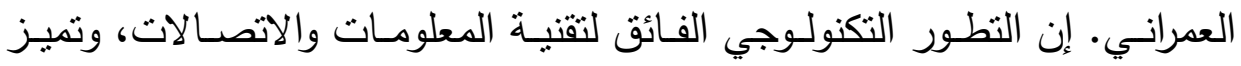
شبكات الاتصال عبر المدن بزيادة التدفقات المادية وغير المادية بجميع أنواعها،

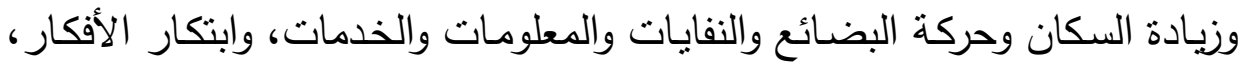
ونمو رأس المال والعمل، كل هذا يتحدى فكرة الحدود العمرانية وتخطيط المدن.

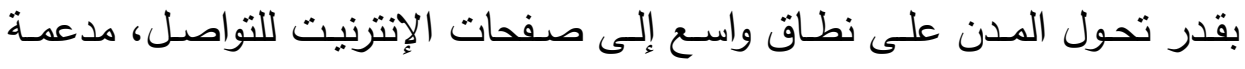

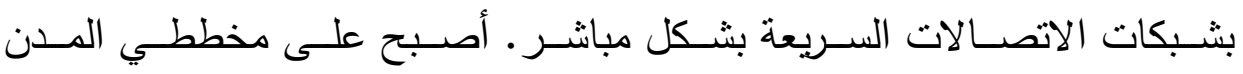

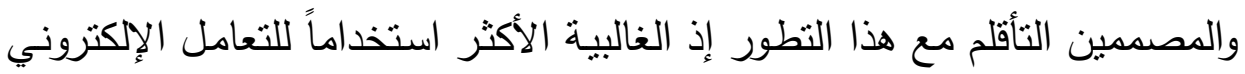

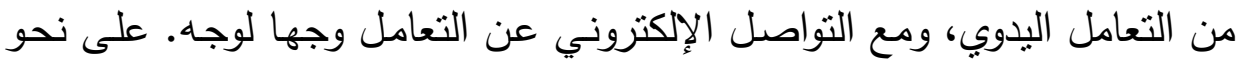

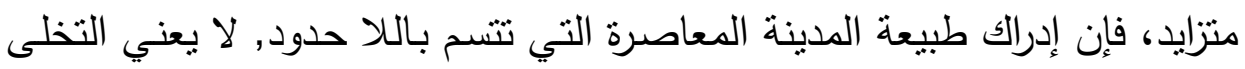
عن تخطيط وتصميم المناطق الحضرية العمرانية بشكل كامل [3]. إن مفهوم المدينـة يخضـع للتغيير نتيجة للنطور التكنولوجي والمعلوماتي ليصبح الثكل الحضري غير مادي. إن التخطيط الحضري التقليدي الحديث الذي

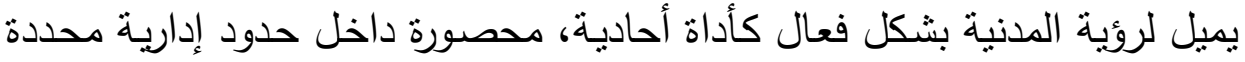
وقابلة للتدخل المـادي على المستوى المحلي. إن التركيبـة السكانية والاجتماعية للمدينة المعرفية من دواعي اهتمام مخططي المدن. كما أن المدينـة تثمل فئاتًا

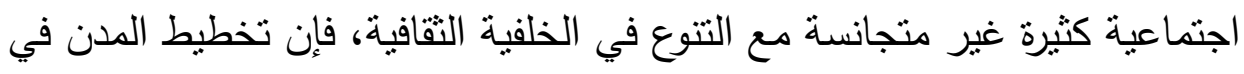
حاجة بالارتقاء إلى مستوى التحدي المتمثل في تلبية لمطالب وممارسات كل هذه الفئات الاجتماعية المختلفة التي تتألف منها ثقافة الحياة الحضرية المعاصرة. إن إن الناء قضية التباين الثقافي وتعدد الثقافـات إلى جانب حل الخلافـات وتوافق الآراء 
الحضرية مع مناهج التخطيط أصبحت الاهتمامات الأساسية في نقاش علم الإدارة الحضرية والسياسات التخطيطية [5.

هذه التحولات في تقنيات مدن عصر المعرفة تتحدى المبادئ الحديثة في جوهر التخطيط الحضري التي تدور حول فكرة وجود مصلحة عامة يمكن تحديدها للمفرد، والمنهج المنطقي "من أعلى إلى أسفل" من خلالها الخبراء المخططين

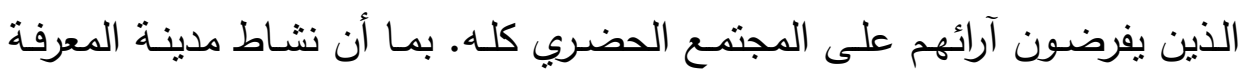

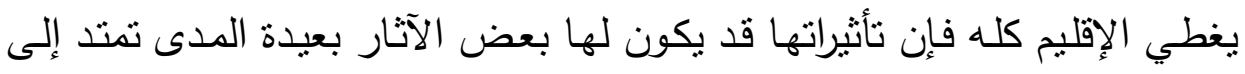

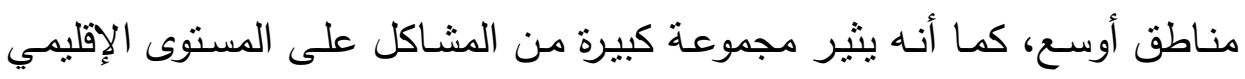

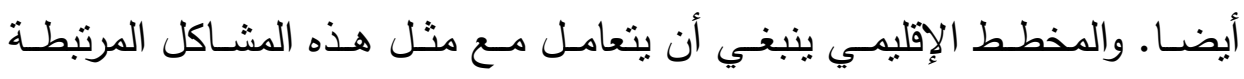

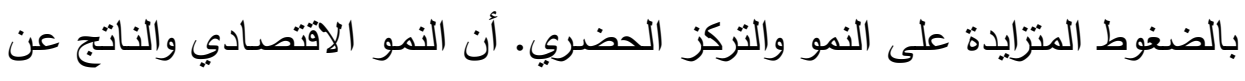

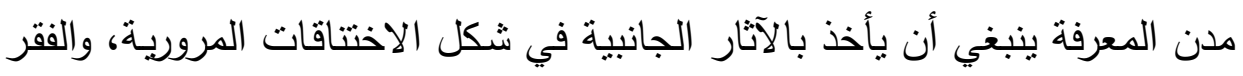

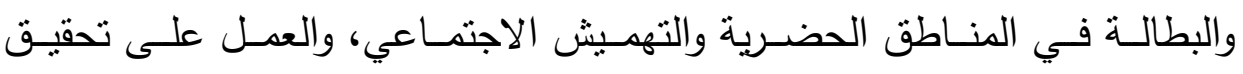

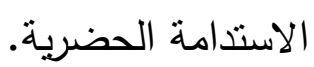

وبسبب هذا التطور المتزامن مـع تتميـة المدينـة المعرفيـة والتغير الجذري

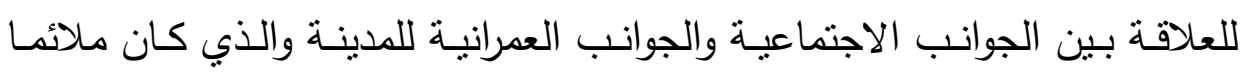

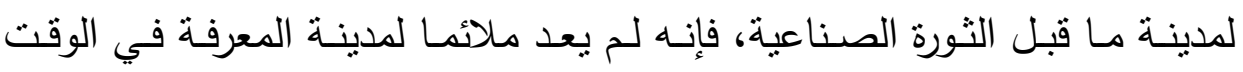

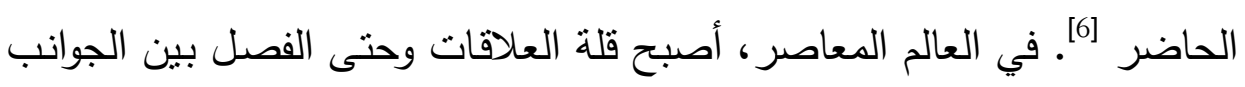

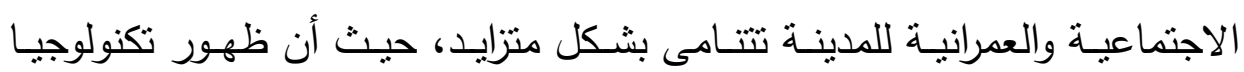

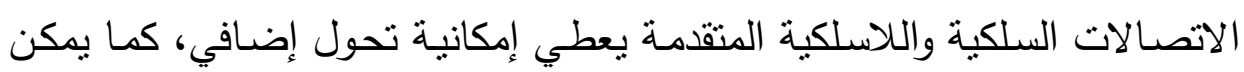

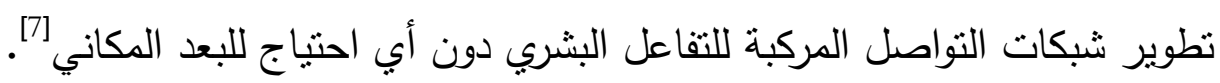

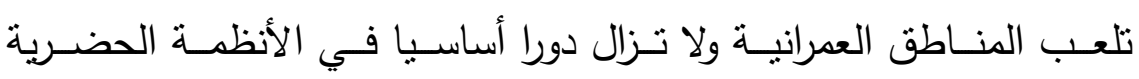

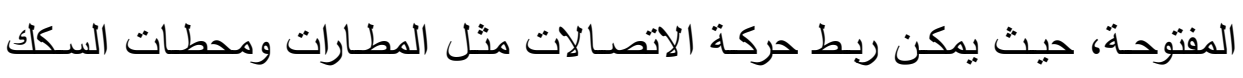

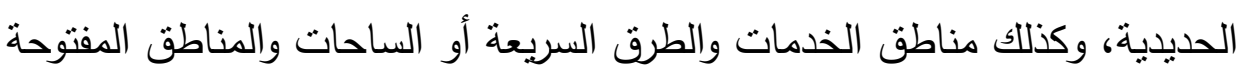


الحضرية والتي لديها القدرة لمنح تتوع وتيرة الاتصـالات الإنسانية التي لا تزال

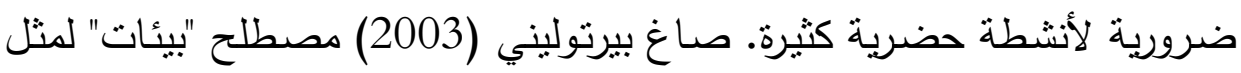

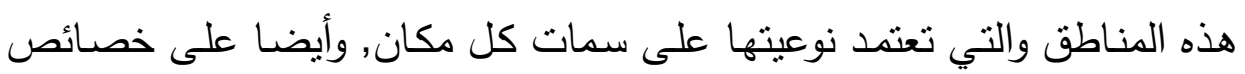

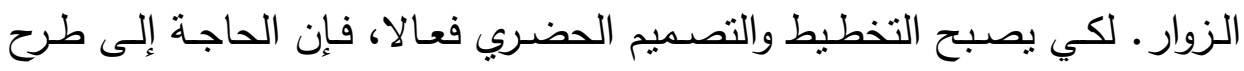

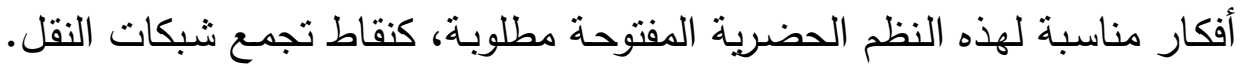

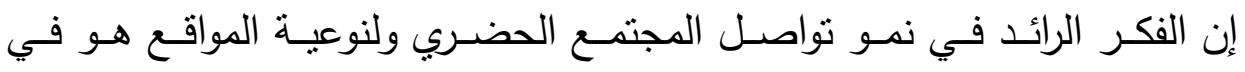

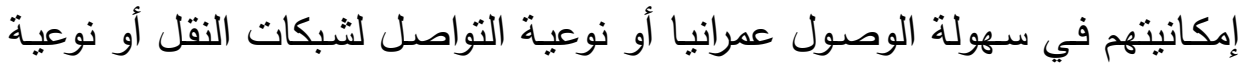
علاقاتهم إلى شبكات وسائل النقل (وعلى نحو متزايد، الاتصالات) على نطاقات

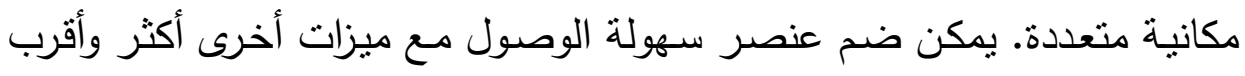

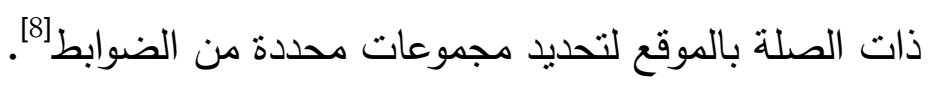

والخلاصة أن السياسات والبرامج التخططية المنوط بها بناء مدينة المعرفة

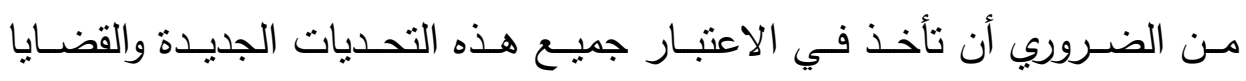

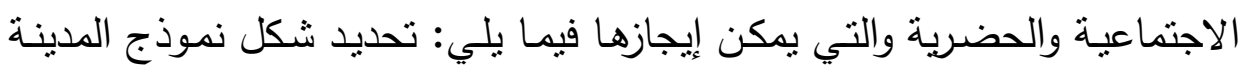
المعرفية وتخطيط استخدام الأراضي الحضرية، وبناء نوافق في الآراء التخطيطية

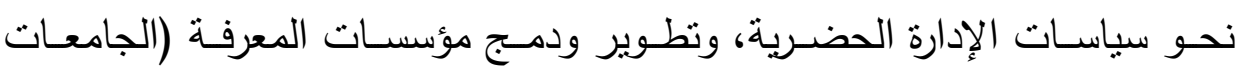

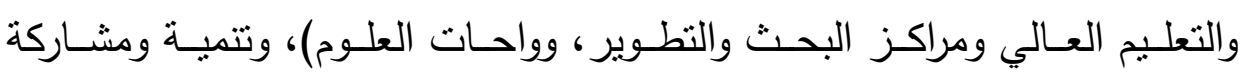

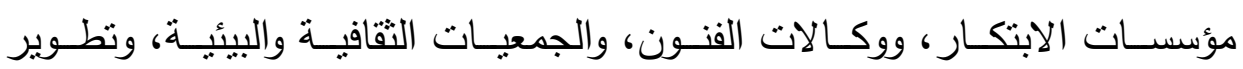

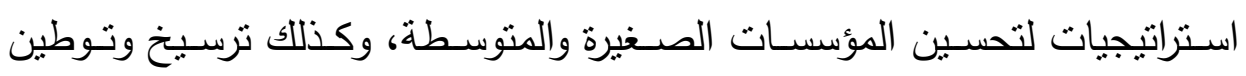
تكنولوجيا المعلومات والاتصالات (ICT).

\section{4. مفاهيم التخطيط المعاصر لمدن الثبكة العنكبوتية}

ترتبط الثبكات العنكبوتيـة للمدن العالميـة بالتقدم الثقني السريع في البنية

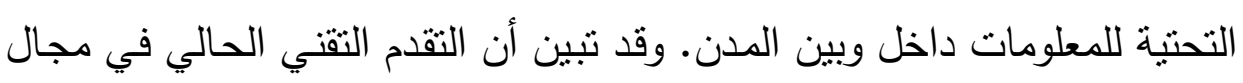

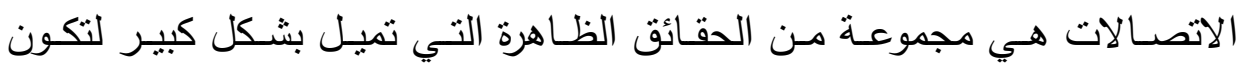


مدفوعة بواسطة مناطق ذات التوجه الدولي العالمي. إن الأنشطة والمهام والحرالك الحضـري التي أصبحت تتركز في مدينـة تعتمد بشكل مكثف على شبكة ذات خصـائص لتسـهيل الاتصـالات السـلكية واللاسـلكية المتطــورة لـدعم التعقيـدات الترابطية المركبـة، ودعم الروابط والتقاطعات عن بعد المتصـاعدة ، سواء داخل المدينـة أو بـين المـدن. وحـين يتعلـق الأمـر بتخطـيط وتصـميم مـدن الثـبكات

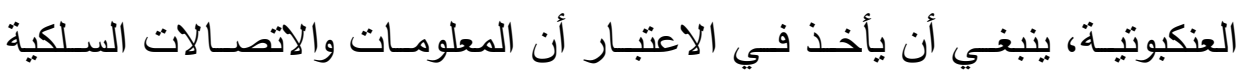
واللاسـلكية سـوف تـوثر في نمـط الثـكل الحضــري القـائم وعليـهـ تحتــاج المــن المعاصـرة إلى إعـادة تفكير في نمط يتلائم مـع مدن الثـبكات العنكبوتيـة وكيفيـة توزيع أنشطتها. أصبحت الأنشطة الحضـرية واستخدامات الأراضـي أكثر تعقيدا. وبتضـح ذلك في زيادة التتوع في أنواع النشاط والحركة الآلية للأفراد والجماعات والثركات

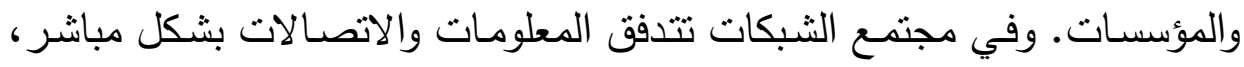
فلا يكون هناك أهمية لتقليص المساحات العمرانيـة ـ في مثنل هذا المشهد، فإن

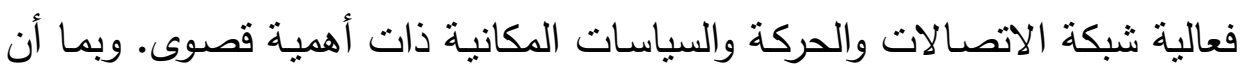
العديد مـن المفـاهيم التقليديـة مثل التخطبط المكاني لا تأخذ هذه التطورات في

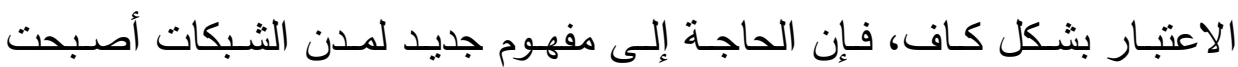

إن المفهوم الجديد للشبكات العنكبوتيـة ينبغي أن ينظر في منظومـة المدينة باعتبارها ديناميكية مفتوحة. إن التفاعل بين الإنسان والأنشطة في الواقع لم يعد يقتصر على الموقع الحضري المحدود المغلق. على العكس من ذللك، فإنها تميل إلى التوسع في الفراغات العمرانية والبصرية بشكل أكثر من أي وقت مضىى. إذا اصبحت النظريات والسياسات الحضرية تتالائم مع مدن الثبكات الناشئة، فينبغي أن تعـالج نمو المدن الممتد والتخلي عن فكرة الإغـلاق أو الطبيعـة السـاكنة في مي 
المنظومة الحضرية. لهذا يراعى بذل الجهود الرامية إلى إدماج اعتبارات الحركة

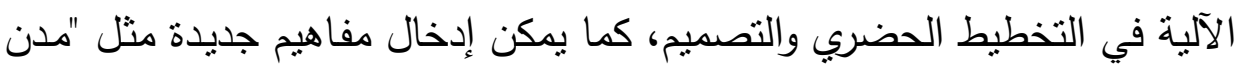

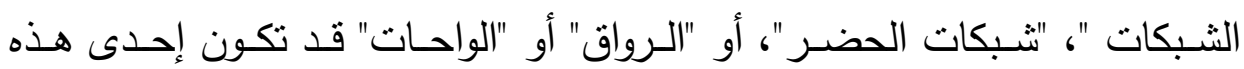
الجهود في الاتجاه الصحيح [3.

مفهوم الرواق المعرفي، ينطوي على التحول من التتمية غير الدخططة

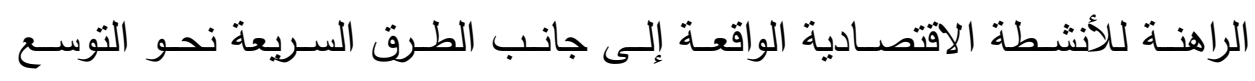

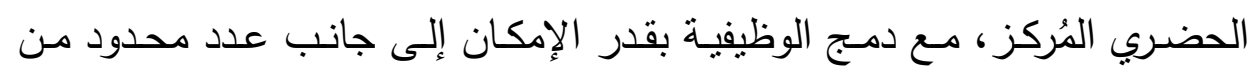

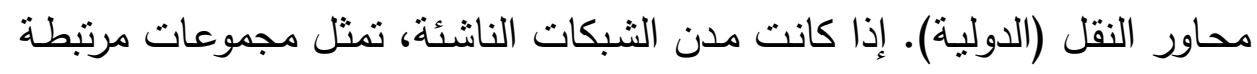

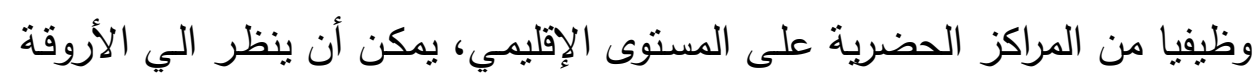
كعناصر فرعية من مدن الثبكات.

إن استراتيجيات التصميم والتخطيط الحضري المعاصرة ينبغي أن تأخذ في

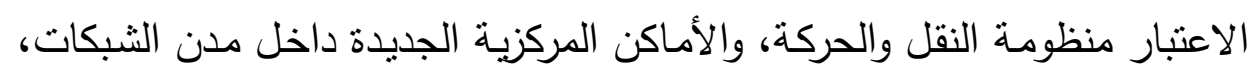

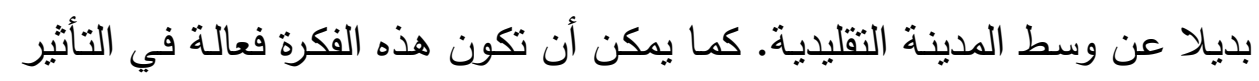

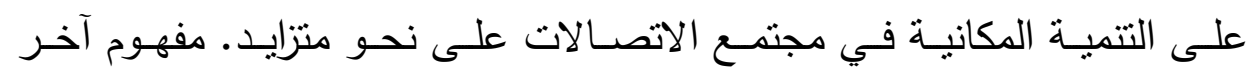

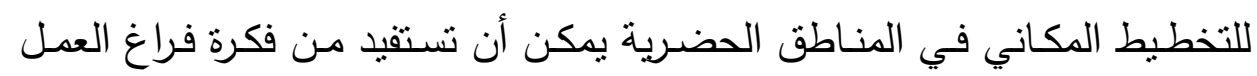
داخل المنطقة والتي يمكن أن تقام فيها الأنشطة.

إن النقاش والجدل الدائر حول شكل مدينة المعرفة والهيكل العمراني يتطلب رؤى فكرية جديدة. هذه الفرضية بمثابة أساس لتحديد نماذج جديدة للتنظيم المكاني ولاستكثاف أثنكالا لمواقع شبكات عنكبوتية متميزة في مدينة المعرفة المعاصرة.

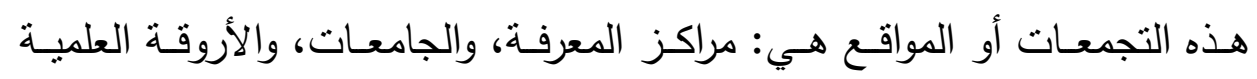

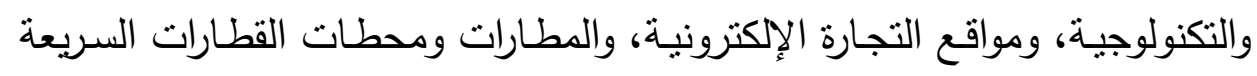
ومناطق التجارة الحرة ومناطق الإنترنت الدجاني، وتجمعات النقل والإمداد المتعدد 
الوسائط المخصصة للثحن. ففي مدن المعرفة، هناك مواقع للتبادل المعرفي توفر بيئة مناسبة لابتكار نماذج جديدة لتخطيط مراكز معرفية جديدة.

\section{4-1 تجمعات ومناطق ابتكار المعرفة}

المعرفة والابتكار هي في صميم فكرة مدن المعرفة. مثل هذه المدن تثميز

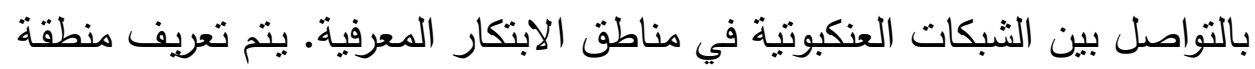
ابتكار المعرفة (Knowledege Innovation Zone - KIZ) باعتبارها الحيز

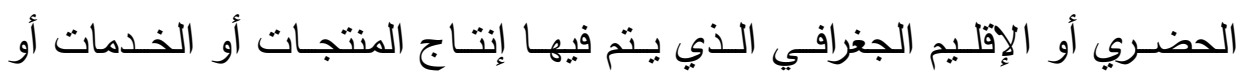

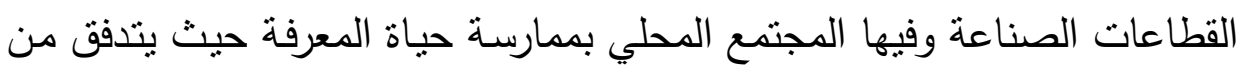

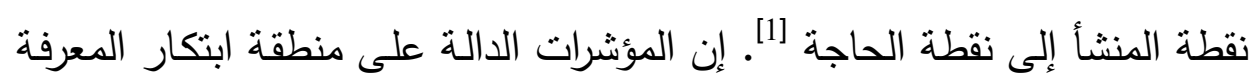
(KIZ)

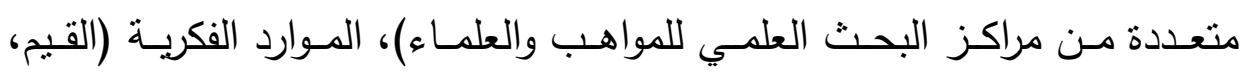

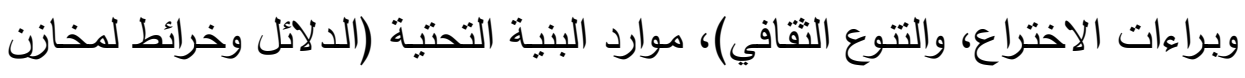

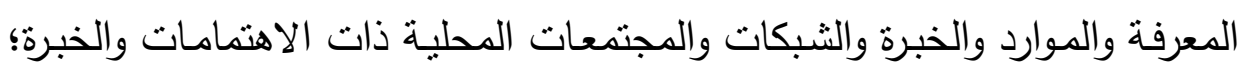

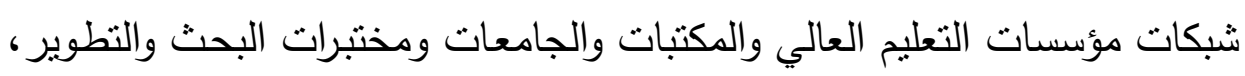

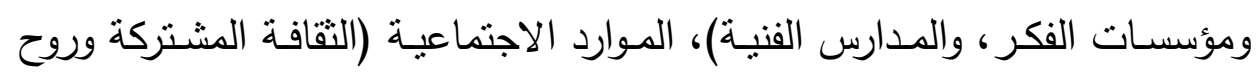
الابتكار والإبداع .... الاحترام الجماعي لمعارف الثعوب الأصلية والمحلية).

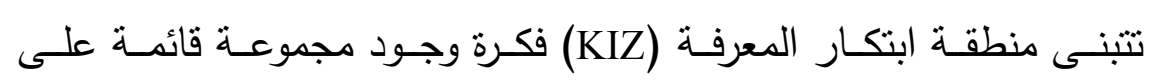

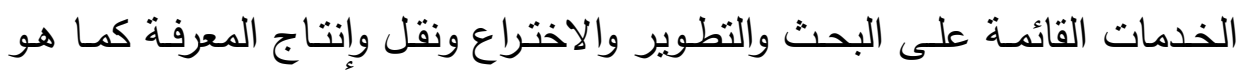
الحال في "وادي السيليكون" بالولايات المتحدة. لتحقيق هذا الهدف، ينبغي تطوير

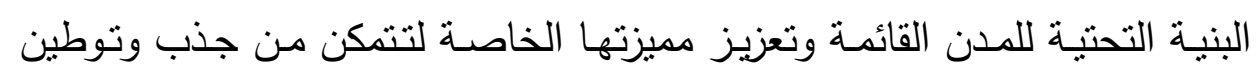

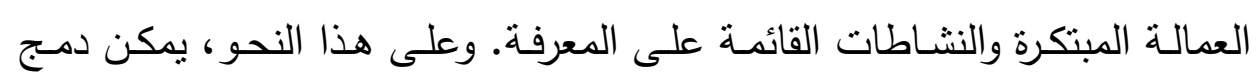

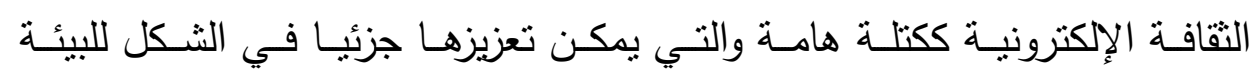


العمرانية. كل هذه التطورات تهدف إلى إعادة تعريف المزايا التتافسية للمدينة من خلال محاور سريان المعلومات العالمي.

2-4 مراكز الابتكار (التجارة الإلكترونية، مناطق التجارة الحرة)

مواقع التجارة الإلكترونيـة جانب آخر لمدينة المعرفة التي ينبخي أن تأخذ

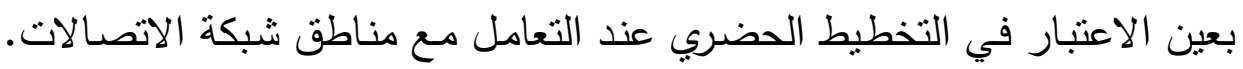
هذه الفراغات والمراكز هي نتيجة طبيعية للنمو السريع للتواصل الرقمي للإنترنت

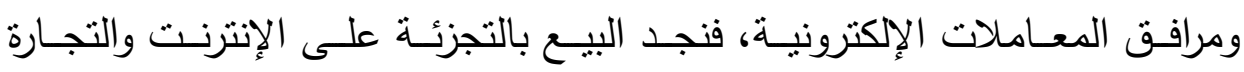

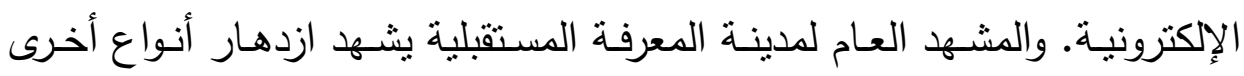
كثيرة من مناطق شبكات الاتصال لتجارة التجزئة الإلكترونية على سبيل المثال

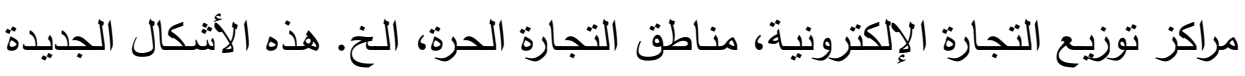

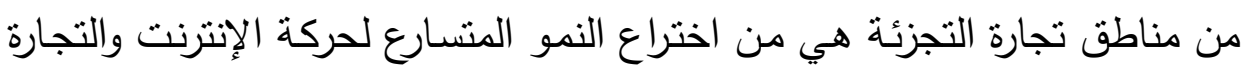

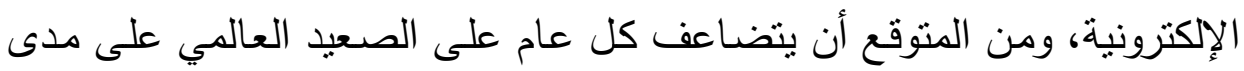

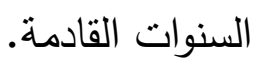

إن تخطيط المدن والتصميم الحضري ينبغي التأقلم مـع التشكيل المكاني

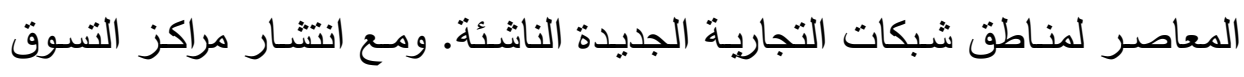

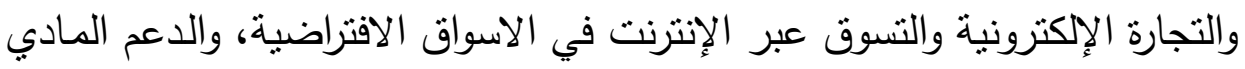

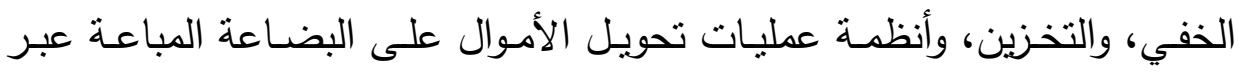

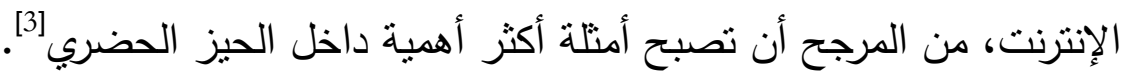
قدر في عام 2010م أن حوالي نلث الأعمال في العالم بـ 60 نريليون دولار

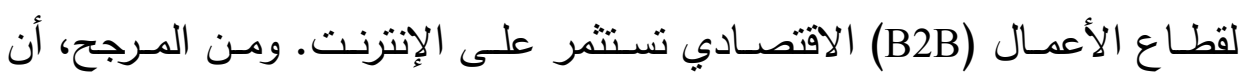

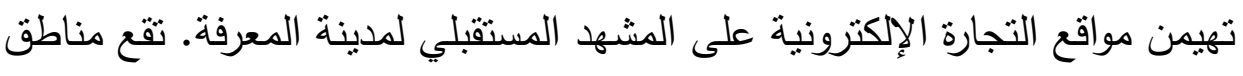
التجارة الحرة (Free Trade Zones-FTZs) في نطاق الضرائب المنخفضة، وقلة 
حزمة القوانين، والتي أصبحت مـاذا للتجارة العالمية. كما تقع في مواقع متمبزة بالاتصـالات عاليـة الجـودة مـن البنيـة التحتيـة اللزمـة لوضـعهم داخل التدفقات العالمية للتجارة والمعاملات التحويلات وتقع عادة في المدن الحدوديـة أو الموانئ الجوية والبحربة.

3-4 مؤسسات التعليم العالهي

الجامعات هي المؤسسات التعليمية الهامة لمعالجة أوجه قصور المدينة في "اقتصـاد المعرفـة". إن الجامعـات مـع مراكز البحوث والتطوير R\&D، وواحات العلوم والتكنولوجيا تشكل كتلة معرفية محوريـة مبتكرة لازمة لدعم القدرة التنافسية للمدينة. توفر مؤسسات التعليم العالي في المدينة مـع الخريجين الموهوبين، ومـع تقديم التتعلم المسـتمر وتـدريب العـاملين في مجـال المعرفـة لمسـاعدة واجتذاب واستبقاء الثركات العاملة في المعرفة.

\section{5. نماذج عالمية لمدن المعرفة}

في السـوات الأخيرة، أخذت العديد مـن المدن في مختلف أنحـاء العـالم المبادرات التي تتطوي على تطويرهـا لمدن المعرفـة والتي أسست مجموعـة مـن المفردات التخطيطية والتصميمية الرامية إلى استخلال إمكانات أو أصسول قدرتها التنافسية وبنـاء اقتصـاد المعرفة على قاعدة قويـة. ولضـمان النجاح والتفوق في عصر المعرفة طورت المدن القائمة على المعرفة ثقافة انتشار المعرفة، واستثمرت في جذب وتتشيط الحراك الحضري لجذب واستبقاء العاملين ذوي المهارات العالية والموهوبين، للاستفادة الكاملة من الاقتصاد المعرفي الحديث. لقد عززت عدد من المدن العالميـة أصسولهم التتافسية عن طريـق إيواء العمال الموهوبين في شركات صــناعة الخـدمات المعرفـة. بفضـل التقـدم التكنولـوجي والاتصــالات الســلكية واللاسلكية [3]. 
وضخت بعض المدن حصصًا أكبر من استثماراتهم في تكنولوجيا العلوم المتقدمة، والبنية التحتية التقليدية، والاستراتيجيات في مجال الفنون والتقافة، كما

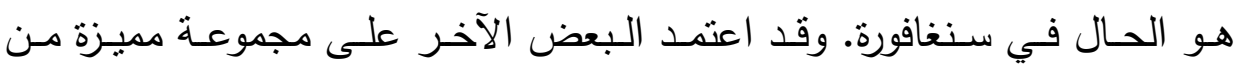

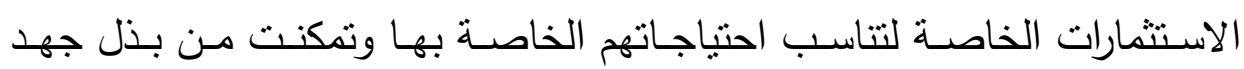
لتصنيفها مدن معرفية. وسيعرض في هذا الجزء ملخص بجدول 1 لبعض النماذج التهن

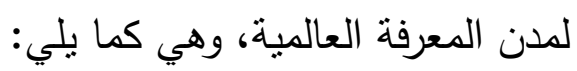

5-1-5 نموذج سنغافوة

الاسم الرسمي هو جمهورية سنغافورة تقع على جزيرة في جنوب شرقي آسيا.

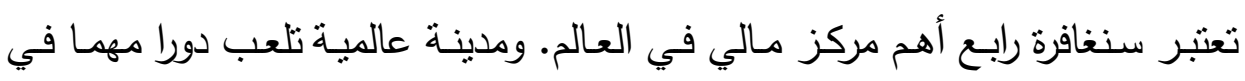

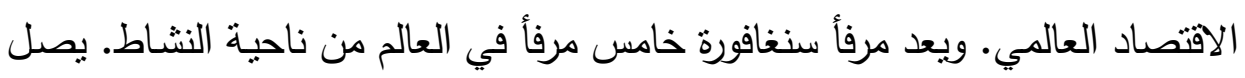

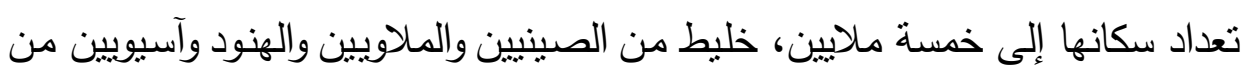

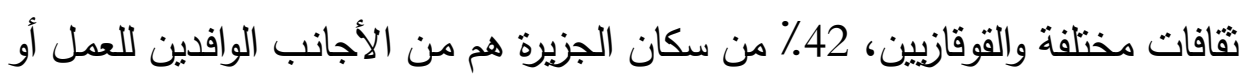
للاراسة وتعتبر سنغافورة ثاني دولة في العالم من ناحية الكثافة السكانية بعد موناكو .

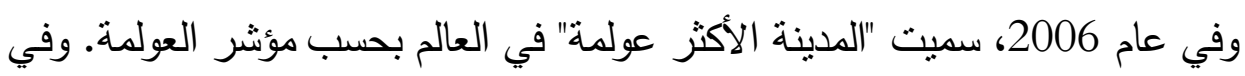
مؤشر جودة الحياة حصلت سنغافورة على الدرجة الأولى في آسيا والمرتبة الحادية عشرة على مستوى العالم [9].

سنغافورة هي مدينـة الجزر يعيش فيها 5 مليون نسمة، 90\% منهـا لديها خدمة الإنترنت من المنزل مع مستوى معيثي مرموق ودمج التكنولوجيا في الحياة

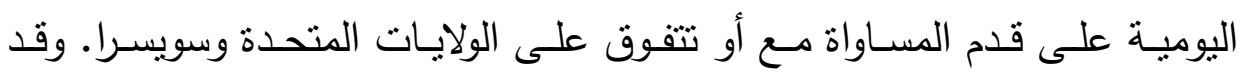

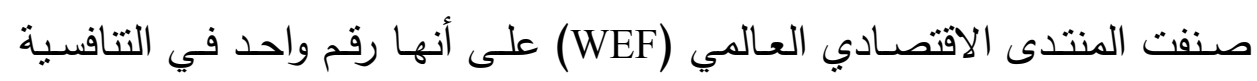

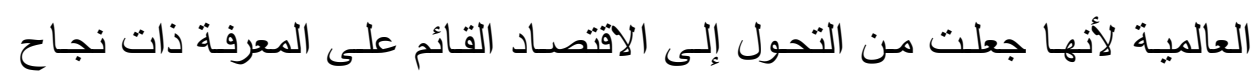

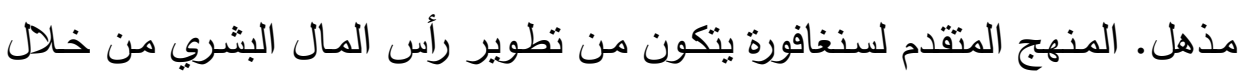


الاسـتثمار في التعلـيم والتعلم والتـدريب، فضـلا عـن تشـجيع وجذب والاحتفـاظ الأشخاص، وذوي الكفاءة الموهوبين. كما أن المكون الثقافي التقي في المدينة لم يتتم استبعاده. كمـا أنها اعتمدت استراتيجية ترسيخ الفنون والتقافة الذي يتمحور حول النشاطات في إطار الكفاءات الدولية. وقد تم تصميم "أوبرا ليريك سنغافورة" و "إسبلاناده" على وجه التحديد لخدمة هذا الغرض.

ففي عام 1960م، كان وضـع المدينـة مماثنا لمدن كثيرة حول العالم وفي أقل مـن 30 عامـا فقد أصبحت واحدا مـن أكثر الاقتصـادات حيويـة في العـالم. بدأت سنغافورة بنـاء القدرة التتافسية من خـلال تحديث مرافق مينائها. ففي عام

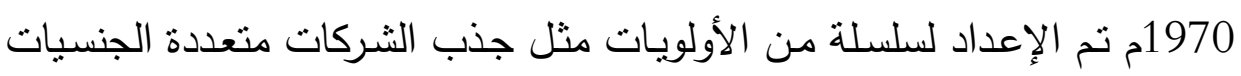

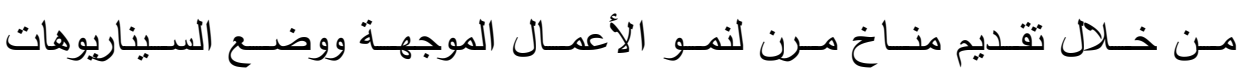
الاستراتيجية لتقييم خيارات المستقبل [3ن

\section{5-2 نموذج بوسطن - الولايات المتعدة}

بوسطن أو بوستن هي عاصمة كومنولث ماساتشوسيتس، الولايات المتحدة، والمدينـة الأكبـر بهـا. وهـيَ العاصـمة غيـر الرســية للمنطقـة المعروفـة بـإنكلترا الجديدة، وهي أهم المدن الكبرى في الولايـات المتحدة ،وأيضـاً واحدة من المراكز العلمية الكبرى بالولايات المتحدة، وبها جامعة هارفارد - إحدى أقدم جامعات العالم

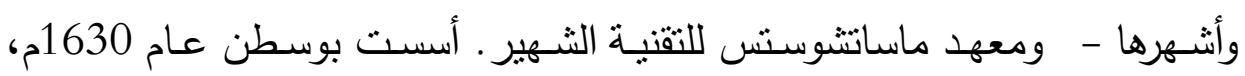

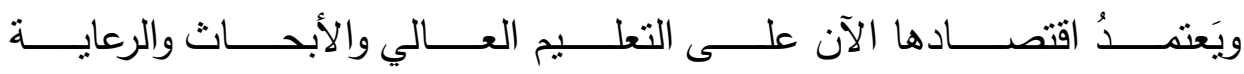
الصحية والتمويل والتقنية وبالدرجة الأولى على التقنية الحيوية]"9 إن الحفـاظ على حالـة مدينـة المعرفـة يعنـي خلـق والتكيف باسـتمرار مـع الأفكار والمفاهيم والعمليات والمنتجات ويرجع لهم القيمة الاقتصادية. تجربتين من لهن مدن المعرفة همـا: التراجع النسبي في أكسفورد وارتفاع سريع في بوسطن على 
الرغم من أن الأولى تمثلك الصداره في التعليم والسياحة ثم الهندسة والنشر ، في

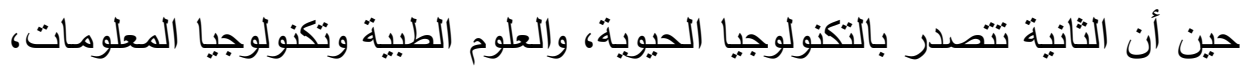
ثم التعليم والخدمات المنيـة والمؤتمرات والفعاليات في القطاع الطبي (السياحة المتخصصة) [3 النعطم الخمات 5-3 حالة مونتريال - كندا

مونتربال مدينة كندية، وهي أكبر مدن مقاطعة كيبك وأكبر مدينة كندية حتى

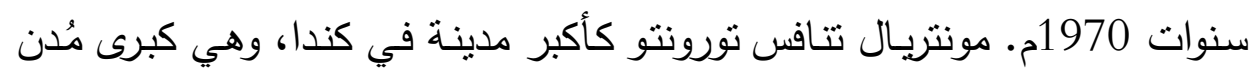

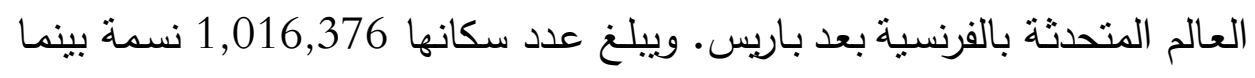

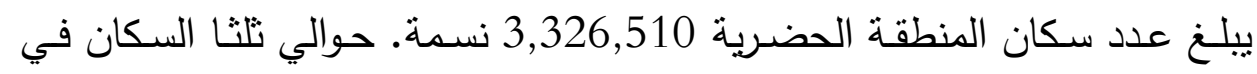
مونتريال من ذوي الأصول الفرنسية، ويتحدثون الفرنسية. وتعتبر مونتريال واحدة الحفية

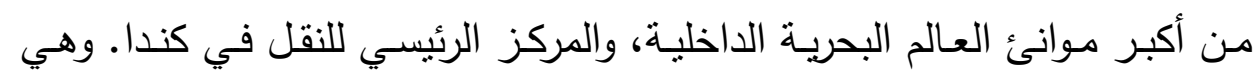

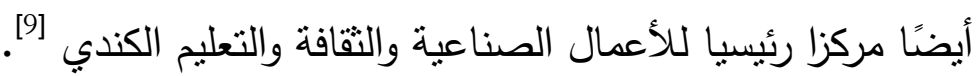
للارتقاء بموقعها كمدينة المعرفة على المدى المتوسط والطويل، اختارت

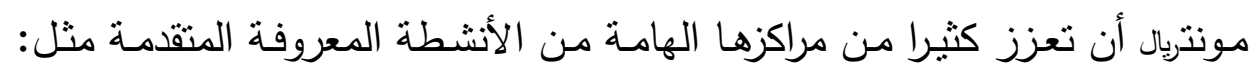

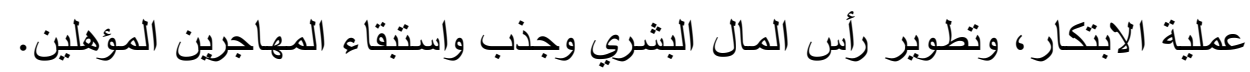

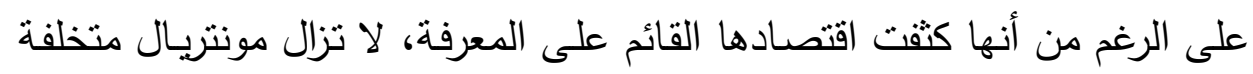

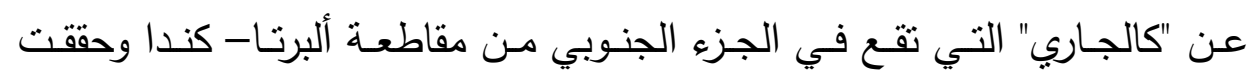

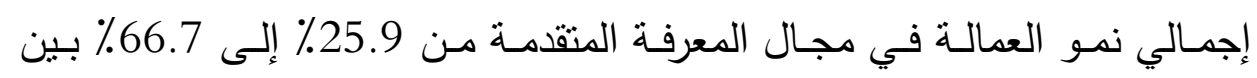

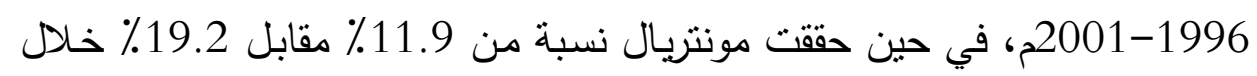

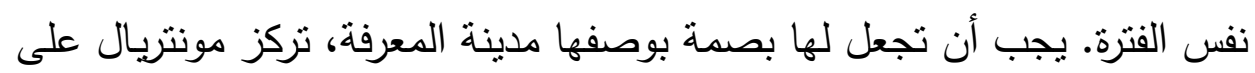
نوعية مؤسساتها التعليمية. وأفضل نوعية من الكليات والجامعات، وارتفاع الكفاءة لهنية 
للمرشحين للمناصب سوف تجذب من جميع أنحاء العالم. وهذا سوف يساعد أيضا

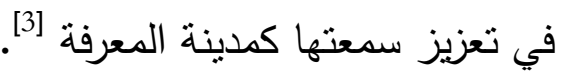
5-4 نموذج ملبورن - استراليا

ملبورن عاصمة ولاية فيكتوريا الأسترالية، وثانية المدن الكبرى في أستراليا،

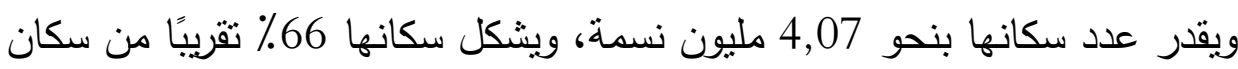

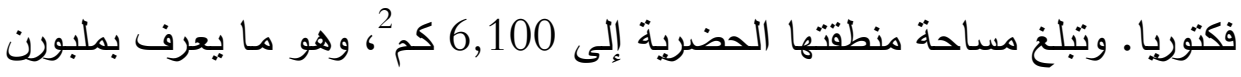

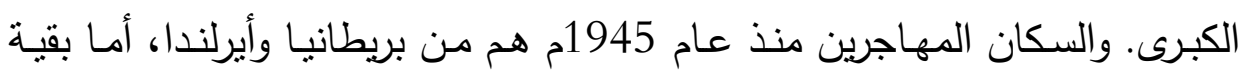
المهاجرين فمن بقية أقطار أوروبا ودول جنوب شرقي آسيام آسيا. تعد ملبورن المركز

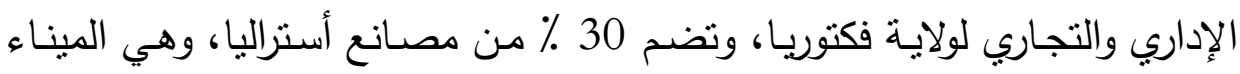

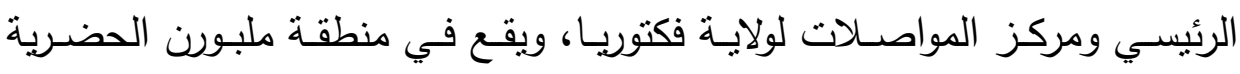

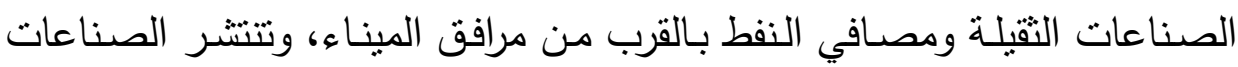

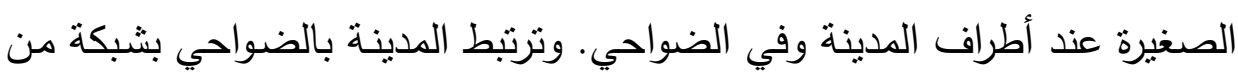
خطوط القطارات الكهربائية التي تسير تحت الأرض. ويُعد ميناء ملبورن من أكبر موانئ الثحن في أستراليال] ركز نهج ملبورن على تتمية اقتصاد الدولة مع الكتلة الهامة الهتوافقة لدعم

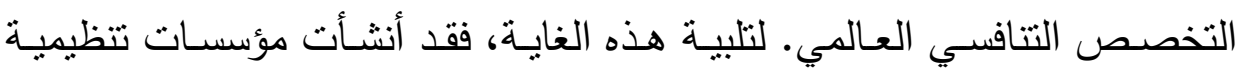

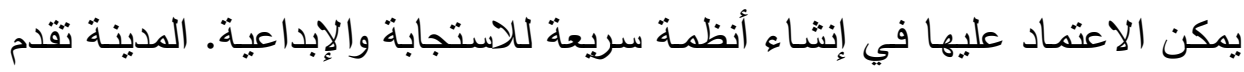

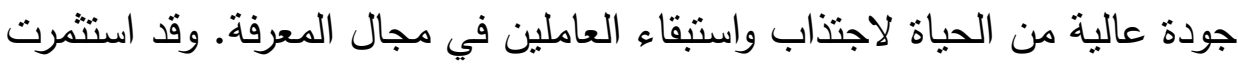

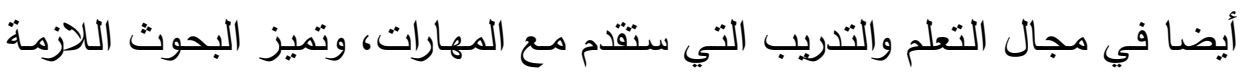

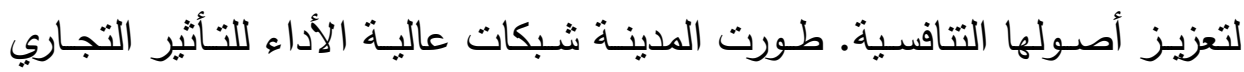

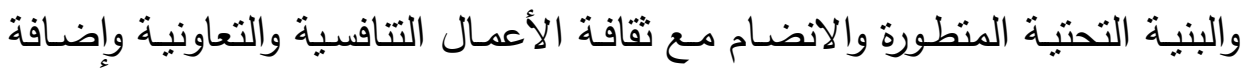


مجتمع شـامل، منفتح ومتسـامح مـع نمـوذج تعـاوني للتنفيذ لنجاح الانتقال إلىى المدينة في عصر المعرفة [10].

\section{5-5 5مونج برشلونة - أسبانيا}

تقع برشـونة على السـاحل الثـمالى الثـرقى لثبه جزيرة إيبيريـا، على الثى

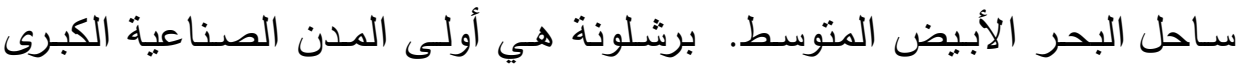

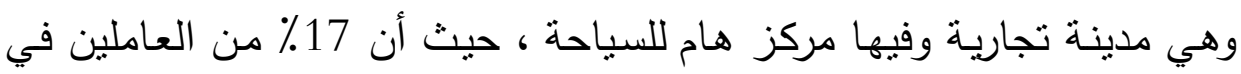

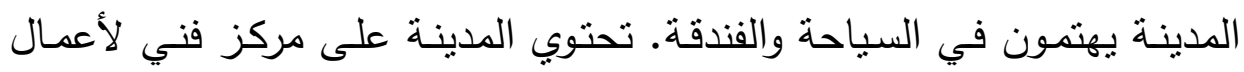

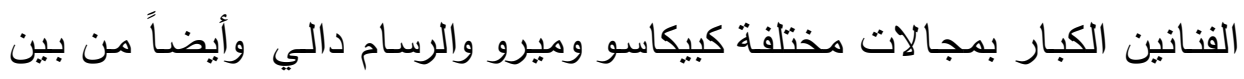

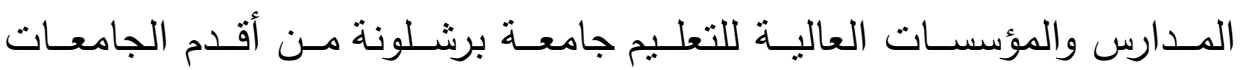
الأوروبية. [9]

برشـلونة عملت للتوجها إلى عصـر المعرفة مـن خـلال تطوير أصسولها

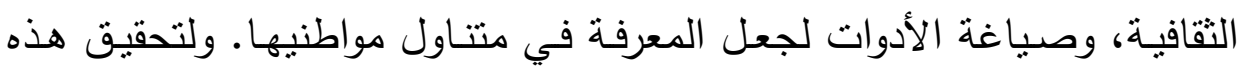

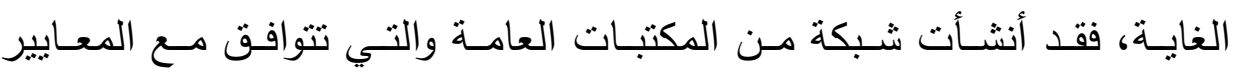

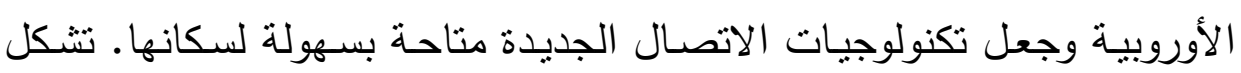

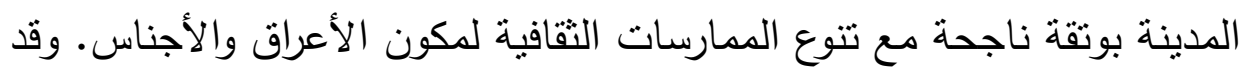

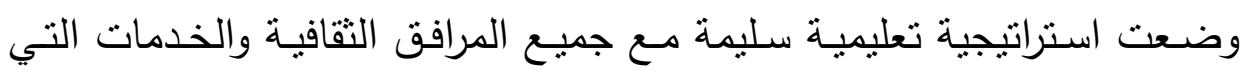

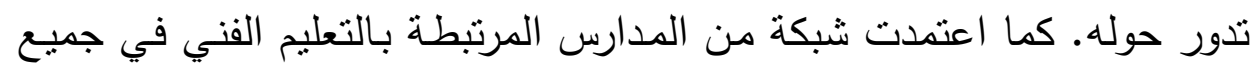

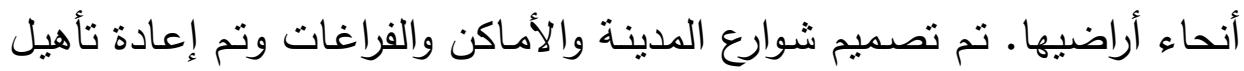

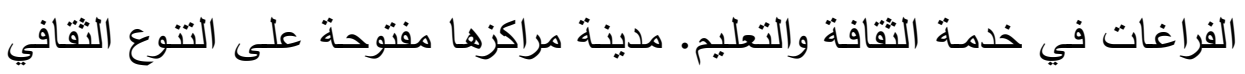
وتثجيع العلاقات وجها لوجه. المدينة لا تتكر لأي شخص ملفه الحق في التعبير 
عن نفسـه بحرية وصـراحة وبجعل كل الأدوات اللازمـة لهم في منتاول الجميع لتلبية هذه الحاجة [3ن.

\section{جدول 1. خلاصة الجواتب والمفردات التخطيطية والتصميمية من النماذج العالمية لمدن المعرفة.}

\begin{tabular}{|c|c|}
\hline الجواتب والمفردات التخطيطية والتصميمية لمدن المعرفة & المدينة \\
\hline 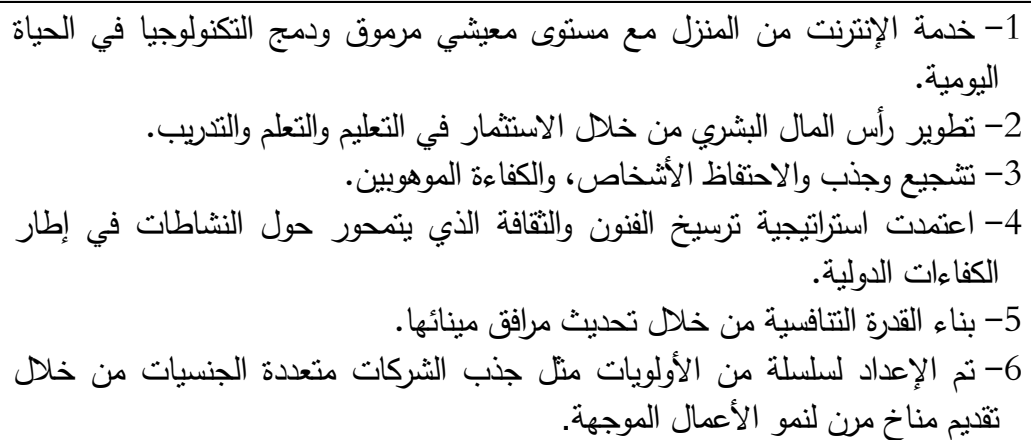 & 1- سنغافورة \\
\hline 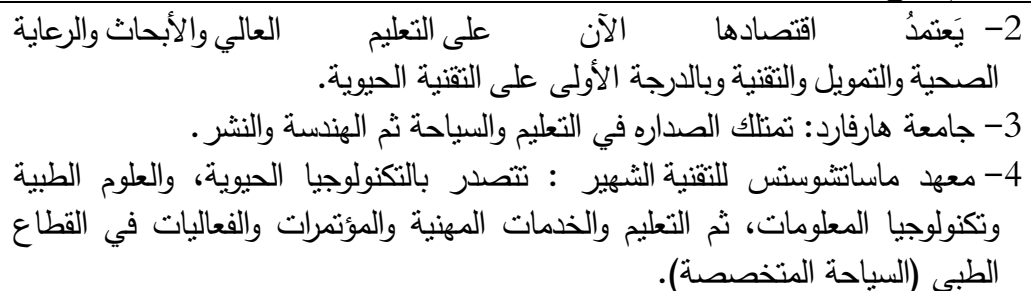 & 2- الولايـــــات - المتحدة \\
\hline 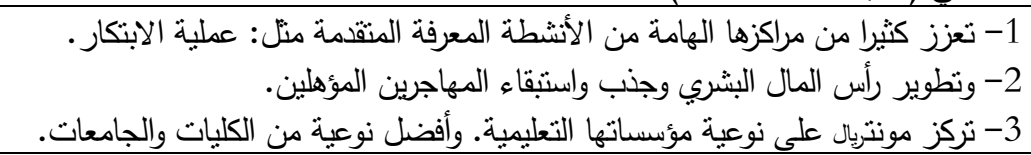 & 3- مونتريـــال \\
\hline 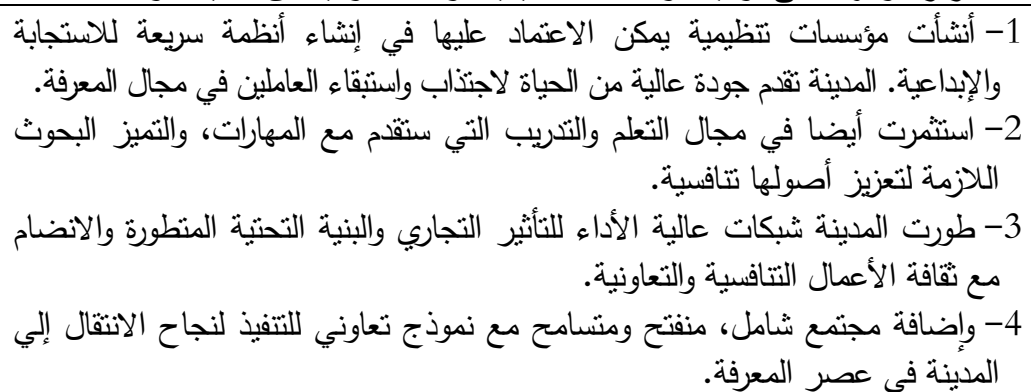 & 4- ملبـورن- \\
\hline 2- أنشأت شير أصولها الثقافية، وصياغة الأدوات لجعل المعرفة في منتاول مواطنيها. & 5- برشلونة - أسبانيا \\
\hline
\end{tabular}




\section{تكنولوجيات الاتصال الجيدة متاحة بسهولة لسكانها.}

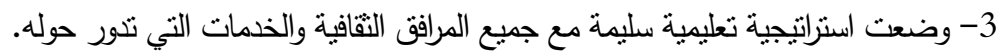

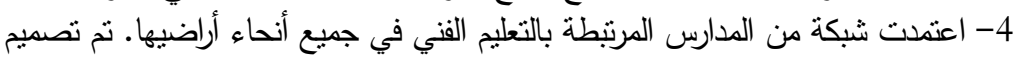

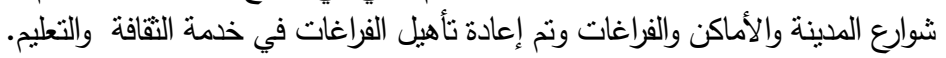

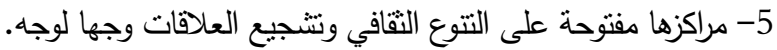

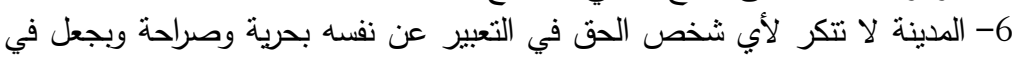
متتاول الجميع كل الأدوات اللازمة لهم لألتيبة هذه الحاجة.

\section{6. آفاق مستقبل حاضرة الامام لتصبح حاضرة المعرفة}

بستعرض هذا الجزء الأوضـاع الراهنة، وأهم القضابا والتحديات التي تواجه جهود التوجه نحو الاقتصـاد القائم على المعرفة على المستوي الوطني، إضـافة إلى استراتيجية التتمبة التي تتضدن عرضنًا للرؤبة المستقبلية والأهداف العامـة، والسياسات، والأهداف المحددة التي تتبناها خطة التتمية التاسعة في هذا الخصوص، كما يناقث الرؤى المستقبلية التي طرحتها المخططات الهيكلية والمحلبة لحاضرة الدمام لحصر أهم عناصر التتمبة القائمة على المعرفة حتى بمكن نقل الحاضرة إلى حاضرة معرفية تتافسبة عالمية.

\section{6-1 الوضع الراهن لنشر ونقل وتوطين المعرفة}

يشكل التعليم المنظومهة الرئيسة لنشر المعرفة في المجتمع. ففي ظل التوجه نحو مجتمع المعرفة، تصاعد الاهتمام العالمي بتتشئة الأطفال، وخاصة خلال مرحلة التعليم ما قبل المدرسي وعلى المستوى الوطني، فتدل إحصاءات وزارة التربية والتعليم على حصول بعض التقدم في هذا المجال.

أمسا التعليم العام فيشكل الأساس لبناء القدرات التي يتطلبها التحول نحو الاقتصـاد القائم على المعرفة ـ فقد انطلق برنامج الملك عبداله لتطوير التعليم "تطوبر " الذي يعالج أوضـاعًا راهنة تخص التعليم بكل مراحله وتتطلب المزيد من الاهتمام منل : نوعية التعليم، وتأهيل المعلمين، وتطوير المناهج بالتركيز على المواد 
العلمية والتقنية والرياضية، والتوسع في تتمية المهارات وخاصـة مهارات الفكر التحليلي والمهارات اليدوية، وروح المبادرة والابتكار وريادة الأعمال واللغات ، والعلوم المستقبلية. كما تشكل مرحلة التعليم العالي إحدى أهم مراحل البناء للتوجه نحو الاقتصاد القائم على المعرفة. يتضح من الوضع الراهن، أن هناك أوضـاعًا راهنة ذات تأثنر مباشر في نشر المعرفة، تتطلب التطوير، وهي: زيادة عدد طلاب الماجستير والدكتوراه وحجم أنشطة البحث والتطوير ـ ومضاعفة المؤسسات الوسيطة التي تربط التعليم العالي بأنشطة الإنتاج والخدمات، مثل حاضنات الأعمال وحاضنات التقنية، وحدائق العلوم والتقنية، وشركات رأس المال الجريء وغيرها، فمثلا لا يتجاوز عدد الحاضنات في المملكة خمس حاضنات فقط في حين يقدر متوسط عدد الحاضنات في الدول المتقدمة بست حاضنات لكل مليون نسمة [11]. وعليه تسعى المملكة إلى نقل المعرفة وتوطينها، ثم إنتاجها محلياً، وذلك من خلال نقل التقنية عبر شركات القطاع الخاص، وشراكاتها مع الشركات الأجنبية الرائدة، فضلا عن التعاون مع المؤسسات العلمية العالمية المتميزة لإنشـاء جامعات ومراكز بحثية في المملكة. وفي هذا الصدد فقد افُتتح عدد من الجامعات الخاصـة ومؤخرًا جامعة الملك عبدالله للعلوم والتقنية ومن قبلها مدينة الملك عبدالعزيز للعلوم

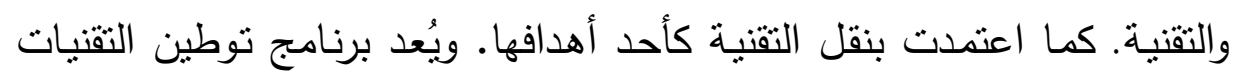
الاستراتيجية والمتقدمة من أهم البرامج في مجال نقل التقنية وتطويرها. ومن جهة

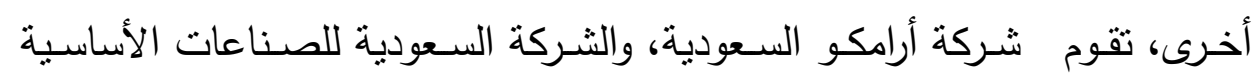
(سابك)، وشركات في مجال الإكترونيات المتقدمة بنشاط مهم في مجال نقل التقنية وتوطينها .ققد عكفت شركة أرامكو السعودية على نقل تقنيات صناعة النفط وتوطينها، وأنشأت لهذا الغرض مركزين للبحث والتطوير ـ ولشركة سابك أيضًا جهود مماثلة في مجال تقنيات الصناعة البتروكيميائية، حيث تم توسعة "مجمع سابك للبحث والتطوير "في الرياض. 
وعليه تتطلب منظومة التعليم معالجة مجموعة من القضايا تتعلق بتطوير

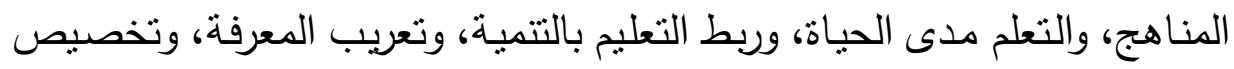
التعليم، وذللك لتحقيق تتمية القدرات التحليلية وامتلاك المهارات العملية، وكذلك تعزيز روح المبادرة وريادة الأعمال. ينطوي هذا النمط التعليمي على أهمية بالغة للوصول إلى اقتصاد قائم على المعرفة ومجتمع معرفي، من خلال تطوير منظومة التطاعلى التعليم.

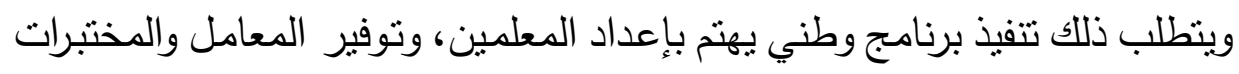

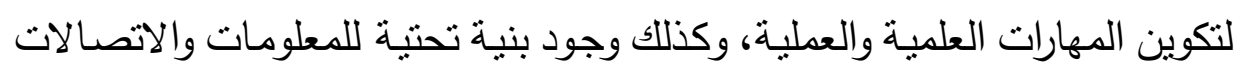
في مجال النعليم [11]

\section{2-6 إنتاج واستثمار المعرفة}

من خلال أنشطة البحث والتطوير والابتكار يجرى إنتاج المعرفة. وقد

استهدفت الخطة الخمسية الأولى للعلوم والتقنية تتفيذ برامج ومشاريع بقيمة 7.9

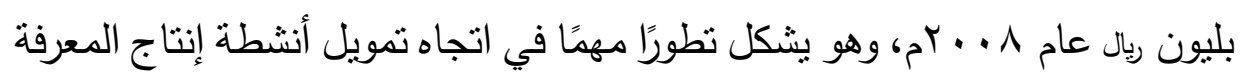
في المملكة. فقد شهدت الجامعات السعودية نموًا في عدد المراكز البحثية خلال و . . . V م حيث تم إنثاء سبعة مراكز للتميز البحثي في مجالات (الدراسات البيئية،

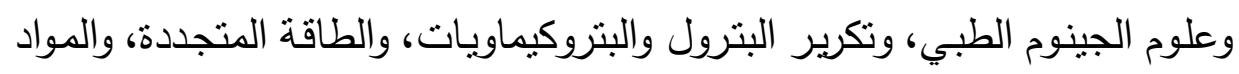

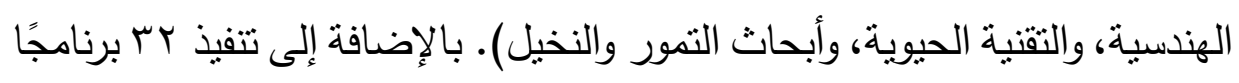

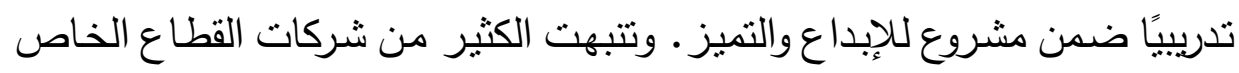

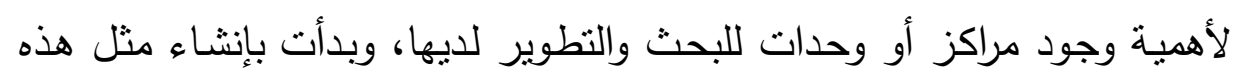

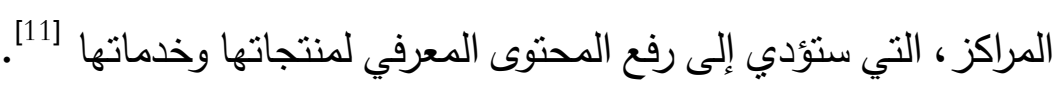
من أجل إيجاد منتجات وخدمات جديدة يعتمد الاقتصاد القائم على المعرفة

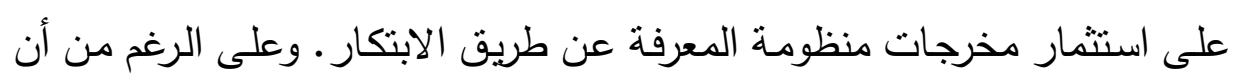

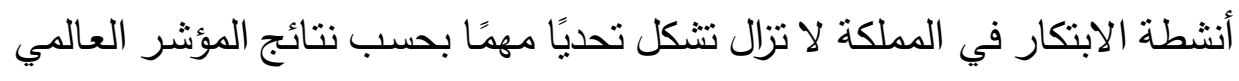

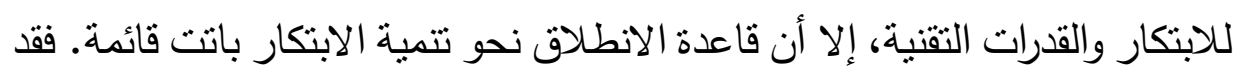


شهدت الصناعات الوطنية مثلا تطورات ملموسة على مدى العقود الثلاثة الماضية، وأصبحت تمتلك قواعد قوية من المعارف التي يمكن البناء عليها للتوجه نحو هذا الاقتصاد الجديد، خاصة بعد إقرار" الاستراتيجية الوطنية للصناعة"، وآلية تتفيذها التي تتبنى قيام اقتصاد قائم على المعرفة، إضـافة إلى "استراتيجية الموهبة والإبداع ودعم الابنكار"، التي جرى اعتمادها.

وعليه يتجسد المحتوى المعرفي أحد الأصول غير المادية في الاقتصاد. ويأخذ أشكالا متعددة في الاقتصاد والمجتمع. ويُعدُّ توطين المحتوى المعرفي في الاقتصـاد القائم على المعرفة بمثابـة تكوين ثروة وطنية. وتواجه المملكة العديد من التحديات في مجال نقل المحتوى المعرفي وتوطينه، ومنها ما يتعلق بالمحتوى المى المعرفي في كل من المنتجات والخدمات، والصادرات والواردات، وفي الثكل الرقمي على الإنترنت، كما يرتبط نقل المحتوى المعرفي وتوطينه بقضيتي استقطاب العقول والاستفادة من التعاون الدولي. ويتطلب مواجهة تلك التحديات بذل مزيد من الجهود وتبني السياسات والإجراءات اللازمة لزبادة المحتوى المعرفي في مختلف الأنشطة والمجالات وبما يسرع من خطوات تحول اقتصاد المملكة إلى اقتصاد قائم على

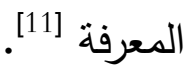

\section{3-6 البيئة المدفزة للمعرفة}

يتطلب نشر المعرفة ونقلها وإنتاجها توافر بيئة محفزة، وذللك بتوفير خمسة عناصر رئيسة تتمنت فيما يلي: البنية الأساسية لتقنية المعلومات والاتصالات:

قد قطعت المملكة خطوات ملموسة في توفير البنية التحتية التي تساعد على خزن المعرفة وتراكمها ونقلها ونشرها، وكذللك اعتمادها قطاعًا معرفيًا إنتاجيًا وخدميًا، بما يؤهلها للتوجه نحو الاقتصاد القائم على المعرفة حيث جرى الانتقال من التعامل 
مـع المعلومات البحتة إلى التعامل مع المعرفة، مثل: استعمال" النظم الخبيرة"، وتوصيف المعلومات، ونظم استخلاص البيانات "التتقيب عن المعلومات"، ونظم

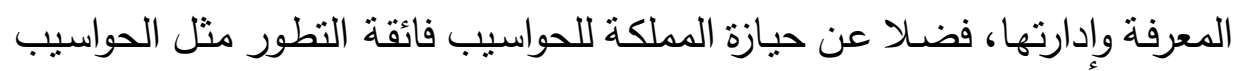

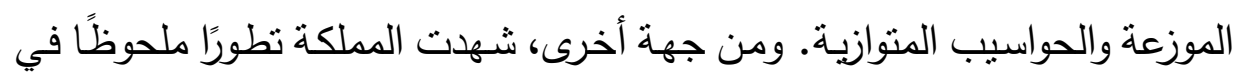
عدد المشتركين في الهاتف الثابت والجوال، وفي شبكة الإنترنت، والنطاق العريض،

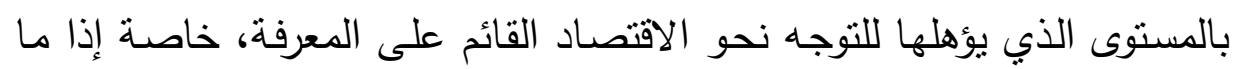
حافظت على وتيرة معدلات التطور المتحققة.

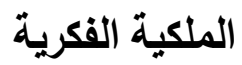

شهدت المملكة تطورًا ملموسًا في مجال حماية حقوق الملكية الفكرية، والتي

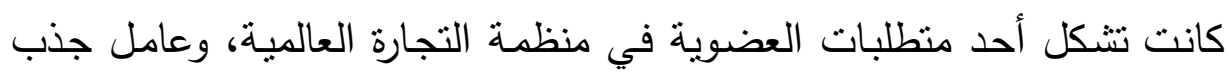

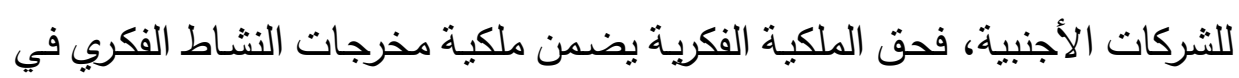

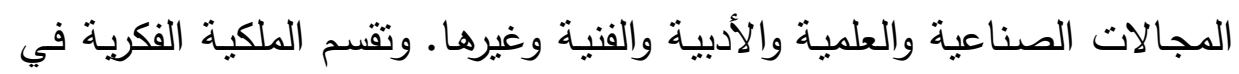

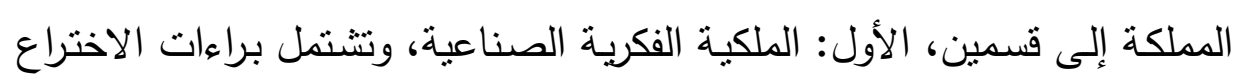

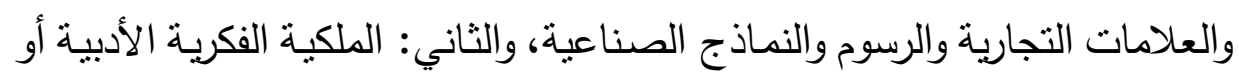
حقوق المؤلف. فحقوق المخترعين، تحظى بالحماية وفقًا لنظام براءات الاختراع

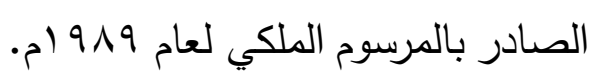

\section{الأنظمة والتشريعات}

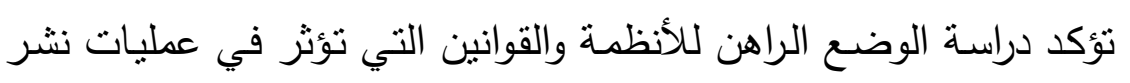

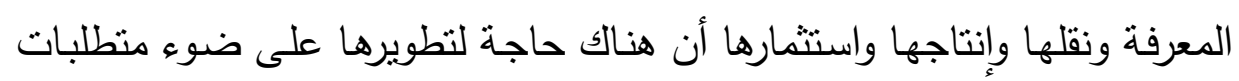
التكيّف مع المتغيرات والمستجدات المحلية والإقليمية والدولية. 
تعد الخدمات المعرفية المساندة من الأدوات المهمة لقيام مجتمع المعرفة

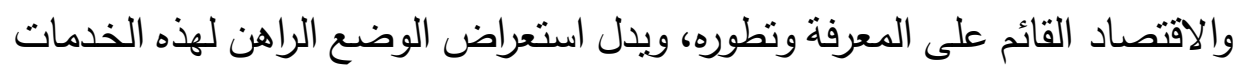

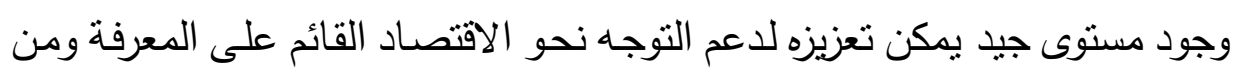

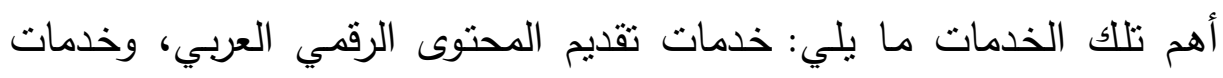
المواصفات، وإدارات المختبرات، والجمعيات العلية.

\section{التوعية والإعلام}

تعد وزارة الثقافة والإعلام الجهة الحكومية المسؤولة عن مختلف وسائل

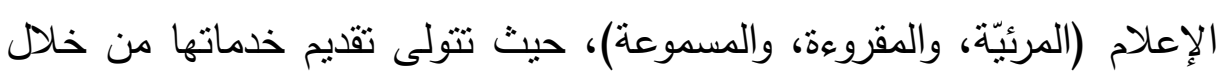

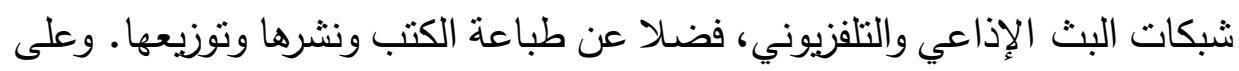

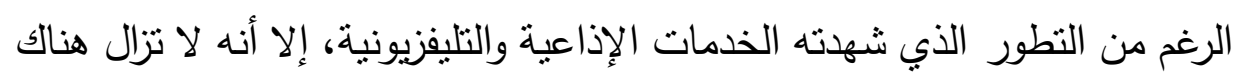

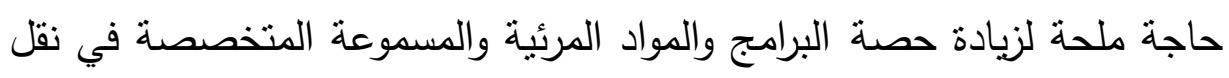

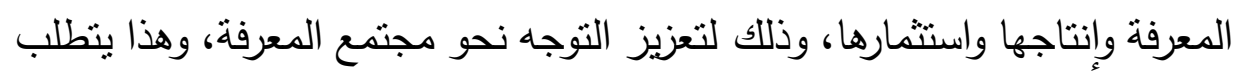
تطوير السياسة الإعلامية والتقافية لتلبية منطلبات مجتمع المعرفة[11].

\section{6-6 مشاريع معزنة للاقتصاد القائم على المعرفة}

شهدت خطة التتمية الثامنة البدء في تتفيذ العديد من المشاريع الكبرى (العامة والخاصة) في مختلف مناطق المملكة، التي تمهد للتوجه نحو بناء الاقتصاد القائم

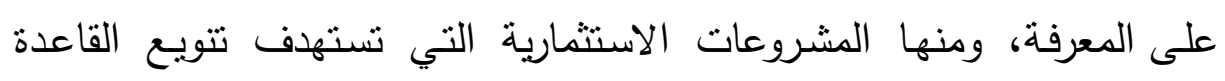

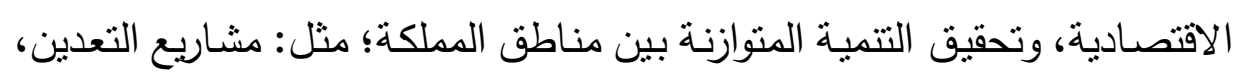

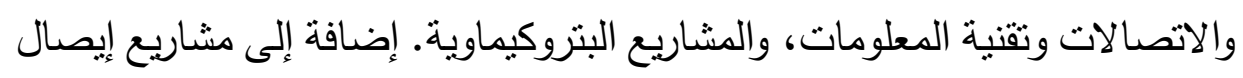

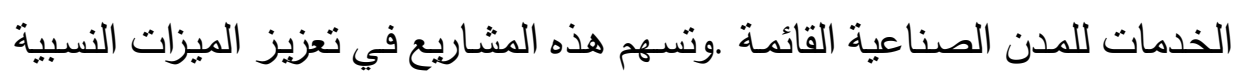

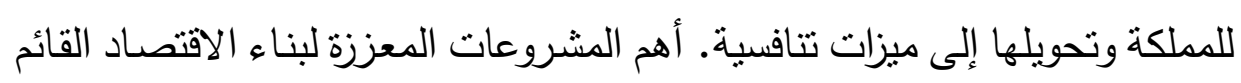


على المعرفة: الددن الاقتصادية الخاضعة لإثراف الهيئة العامة للاستثمار، وحديقة

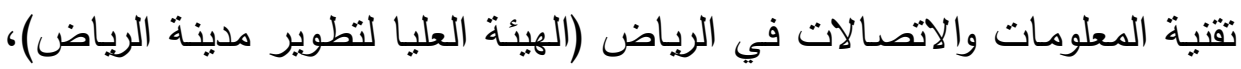

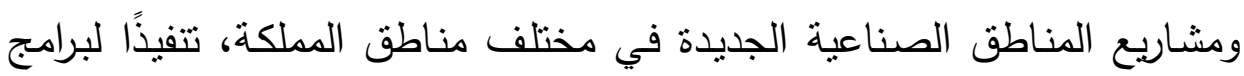

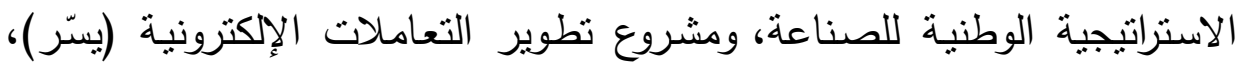

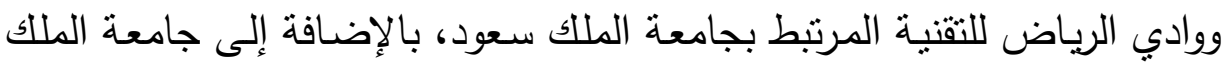

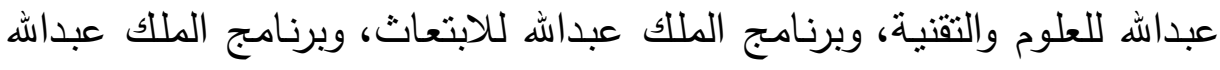
لتطوير التعليم، ومبادرة الملك عبداله للمحتوى الرقمي العربي، ومركز الملك عبداله المالي في مدينة الرياض [11] 6-5 استراتيجية التنمبية - الروئية المستقبلية سيكون اقتصاد المملكة قد خطا خطوات كييرة بحلول عام 2024م نحو الاقتصاد القائم على المعرفة، معتمدًا على مجتمع يعمق من المستوى المعرفي لأفراده علمًا ومهارة وخبرة ، وسيكون قد اقترب من المستويات التي تتهدها الدول المتقدمة

في هذا المجال [11]. الأهداف العامة

- تعزيز التتمية البشرية، ونشر المعرفة، وتوسيع الخيارات لأفراد المجتمع في اكتساب المعارف والمهارات والخبرات.

- تعزيز جهود نقل المعرفة وتوطينه في جميع القطاعات الاقتصادية

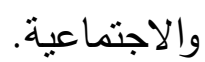

- رفع مستوى قدرات المملكة في إنتاج المعرفة في الحقول الاقتصادية

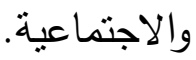

- رفع مستوى المعرفة ومحتواها في الأنشطة الإنتاجية والخدمية في

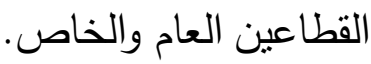


- توفير البيئة التقنية والإدارية والتتظيمية، فضلا عن البنية التحتية لتقنية المعلومات والاتصالات.

- تقليص الفجوة المعرفية بين المناطق، وزيادة وعي المواطن بأهمية المعرفة، وزيادة المحتوى الرقمي العربي.

\section{السياسات}

- اعتماد آليات تفضي إلى زيادة نشر قواعد المعرفة للتوجه نحو الاقتصاد القائم على المعرفة.

- العمل على زيادة قدرات المملكة في مجال نقل المعرفة وتوطينها. - العمل على تحقيق زيادة ملحوظة في أنشطة توليد المعرفة العامة والخاصة.

- تحسين المحتوى المعرفي للسلع والخدمات المنتجة في المملكة، للارتقاء بالإنتاجية والقدرات التنافية. - العمل على توفير البيئة المناسبة لإدارة المعرفة، تقنيًا وهيكليًا ونظاميًا وتمويليًا وإداريًا.

- الرقي بالمستوى المعرفي لأفراد المجتمع. - ماد.

$$
\text { الأهداف المحددة }
$$

- مواصلة زيادة تمويل البحث والتطوير والابتكار للعلوم والتقنية. - مضاعفة معدلات الالتحاق في مرحلة رياض الأطفال. - تحفيز القطاع الخاص للتوسع في الإنفاق على البحث والتطوير والابنكار . 
- زيادة عدد الطلاب والطالبات الذين يحظون برعاية مبادرات" الموهبة

- الارتقاء بمسنوى جودة تعليم العلوم والرياضيات في كامل المنظومة

التعليمية.

- توسيع مشاركة القطاع الخاص في التعليم بمستوياته المختلفة.

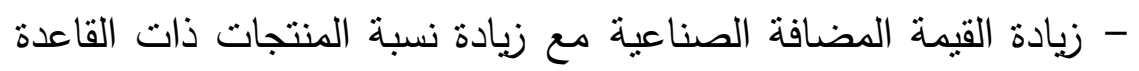
التقنية وزيادة نسب الصادرات الصناعية. - نطوير أنظمة المواصفات والمعايير في جميع المجالات. أصبحت" إدارة المعرفة "من الممارسات الثائعة عالميًا. وتدل دراسة الوضع الراهن لهذه الإدارة في المملكة على وجود قضايا وتحديات تتطلب المعالجة خلال

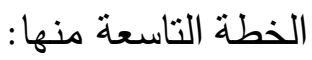

- رسم خارطة طريق للاقتصاد القائم على المعرفة بالتتسيق بين الجهات ذات

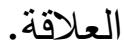

- التتسيق بين الببادرات الوطنية العديدة الخاصة بالاقتصاد القائم على المعرفة. - تبني المملكة لنظم إدارة المعرفة. - توفير حِم منتوعة من الحوافز للاستثمار في الأنثطة ذات الصلة بالمعرفة. - تطبيق معايير الجودة في الأجهزة الحكومية بغية الارتقاء بجودة العمل.

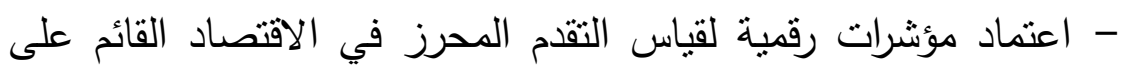

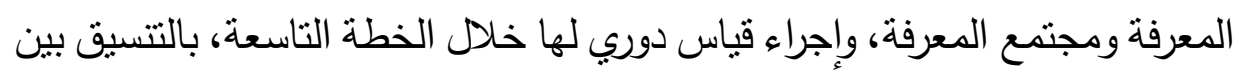
مصلحة الإحصاءات العامة والمعلومات ومدينة الملك عبدالعزيز للعلوم والتقنية ووزارة الاتصالات وتقنية المعلومات. 7. الرؤى المستقبلية للتنمية الحضرية لحاضرة الدمام 
تعتبر حاضرة الدمام الواجهة الثرقية للمملكة على الخليج العربي والبوابـة الرئيسية للمملكة على العالم من الناحية الثرقية. مساحة الحاضرة تجعلها من أكبر المراكز التتمويـة على شـاطيء الخليج العربي. يتم مناقتـة الرؤى المستقبلية التي طرحتها المخططات الهيكلية والمحلية لحاضرة الدمام لحصر أهم عناصر التتمية القائمة على المعرفة حتى يمكن نقل الحاضرة إلى حاضرة معرفية تتافسية عالمية. تبحث حاضرة الدمام لإيجاد دور فعال على مستوى الخليج العربي حيث إن اقتصاد المملكة والقطاع الخاص في الحاضرة أقرب من الإطار المجاور لله. كذلك إيجاد فرص لجذب الاستثمارات المحلية والإقليمية والدولية من خلال إيجاد فرص استثمارية فريدة وذات عائد اقتصـادي عال معتمد على المقومـات التتمويـة الفربدة والمتتوعـة للمنطقة. بالإضـافة إلى تقويـة الدور الإقليمسي للحاضـرة ودعم دورهـا الاقتصسادي والتتموي للمملكة وتحقيق التوازن في توزيع الأنشطة التتمويـة والخدمات. إن الأدوار المسـتقبلية لحاضـرة الـدمام طبقا لرؤيسة المخطط الهيكلي تتمثل في كونها مركزا تجاريا منميزا مما تمنلكه من إمكانات كبرى وارتباطها بدول الخليج من خلال طريق مجلس التعاون، وكونها مركزا خدميا تعليميا صحيا رئيسيا لتوفر الجامعـات والمراكز البحتيـة والمستتـفيات ذات المسـتوى العـالمي. كـذلك فيك احتوائها على مركز للمعارض والمؤتمرات الوطنيـة والدولية وأيضـا مركز رياضي وهي ترفيهي على المستوي الوطني والإقليمي. يتوقع أن يصل عدد سكان حاضرة الدمام 2.5 مليون نسمة عـام 1450هـ [12]. ويوضــح شكل 1 المخطط الهيكلي لحاضـرة 


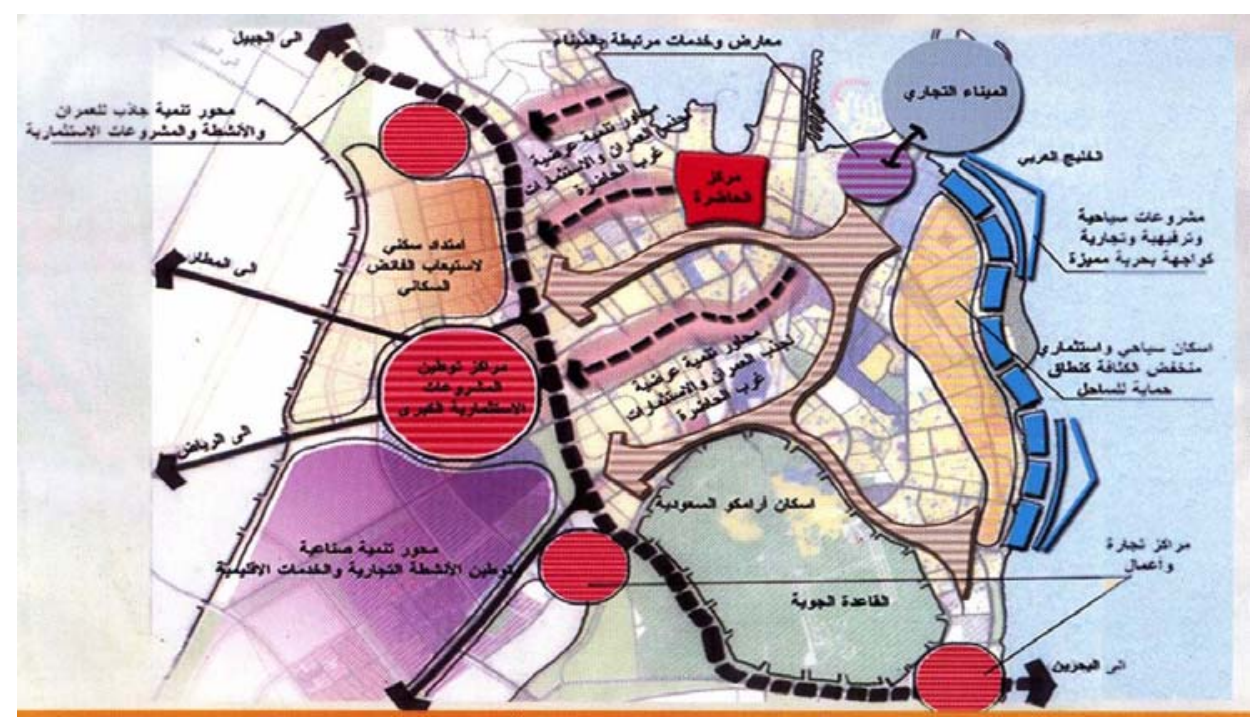

شكل 1. المخطط الهيكلي لحاضرة الدمام لعام 1450هـ.

المصدر : وزارة الثئون البلدية والقروية-وكالة الوزارة لتخطبط المدن، (2007).

تتكون حاضرة الدمام من ثلاث مدن رئيسية هي الدمام والخبر والظهران. يبلغ عدد سكان الحاضرة نحو 1.2 مليون نسمة طبقا لتعداد عام 1425هـ بمعدل نمو 3\%. وتعتمد الفكرة التخطيطية للمخطط الهيكلي لحاضرة الدمام لعام 1450هـ على دفع عملية التتمية على محور طريق مجلس التعاون من خلال مجموعة من المراكز التتموية الكبيرة خارج الكتلة العمرانية الحالية. كما تعتمد على عدة ركائز تتمثل في دفع التتمية باتجاه غرب وجنوب الحاضرة من خلال إنشاء مراكز توطين للأنشطة والخدمات تستقطب الزيادة السكانية المستقبلية، لتقوبة الشخصية المكانية للحاضرة. اعتمدت فكرة المخطط على ربط أجزاء الحاضرة بعضها ببعض بإنشـاء مجموعة من محاور الحركة الرئيسية في إطار منظومة منكاملة من الطرق تتميز بالتدرج الهرمي. تأكيد محاور الحركة وظيفيا وبصريا، وخاصـة المحاور المتعامدة على البحر وطريق الكورنيش. تقليل الكثافة السكانية بقدر الإمكان في المخططات المعتمدة على ساحل الخليج إثر عمليات الدفن وذللك باقتراح أنشطة ترفيهية وكذلك 
استخلال المناطق في قطاع الإسكان السياحي في إطار ضوابط واشتراطات شديدة الصرامة. إضفاء نوع من التخصص الوظيفي للقطاعات المكونة للحاضرة خاصـة المراكز والمحاور التجارية ومناطق الخدمات الرئيسية والحد من التباين والتداخل ما بين الاستعمالات المختلفة مما يعمل على إيجاد بيئة عمرانية منزنة[12] الأهداف التخطيطيـة لمخطط الحاضـرة تتحصر في الحفـاظ على الموارد البيئية المتاحة بالحاضرة وخاصـة ساحل الخليج من خلال منع أي عمليات دفن

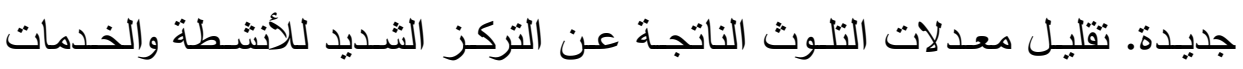
والسـكان بالحاضـرة خاصـة بـالأجزاء المركزيـة منهـا. بنـاء طـابع عمرانـي مميـز يتتاسب مع الأدوار الرائدة المتوقعة للحاضرة على المستوبات المختلفة. ربط اجزاء الحاضرة بعضـها ببعض للتغلب على التفكك والانعزال العمراني لبعض المناطق الناتج عن وجود أحرام الأنابيب والمحجوزات الحكومية. تحسين وتطوير شبكات الطرق من خلال بناء تدرج هرمي واضـح وتقليل التقاطعات على الطرق الرئيسية وتأكيد المداخل الرئيسية للحاضرة. توفير فرص عمل ملائمة من خلال العمل على ولى ولى جذب الاستثمارات المتوافقة مـع المقومـات التنمويـة بالحاضـرة. تحقيق التكامـل مـا بين الأنشطة الاقتصـادية المختلفة خاصـة الأنشطة التجاريـة والسياحية والترفيهية الأمر الذي يدعم اقتصاد الحاضرة وبنميه.

\section{7-1 الإمكانات والمقومات التي تحتضنها حاضرة الدمام في مجال المعرفة} يتم إنتاج المعرفة من خلال ثلاتثة أنشطة: البحث العلمي، والتطوير، والابتكار ، وهي أنشطة يتوجب مضاعفتها في جميع القطاعات، على أن ثتوافق ولق مخرجاتها مع متطلبات الاقتصاد الوطني، ويتطلب ذلك مواجهة العديد من التحديات، أبرزها: تكثيف الجهود الخاصـة بيناء القدرات الضرورية لاستيعاب المعرفة وتوطينها، وزيادة حجم (موارد) البحث والتطوير والابتكار المادية والبشرية، والتوسع في البحوث التطبيقية وفي الابتكار والاهتمام بالمعارف التي تتنافس الدول 
المتقدمة في امتلاكها ولا تتشر ولا يجري تبادلها، وتحفيز القطاع الخاص على

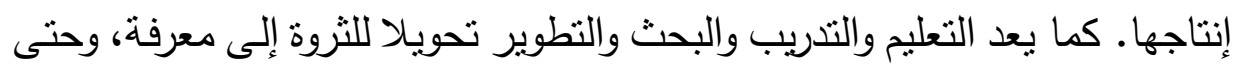

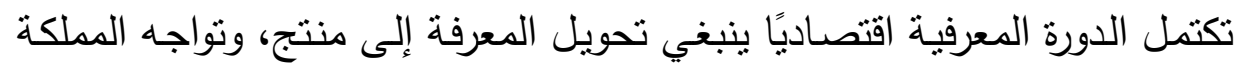

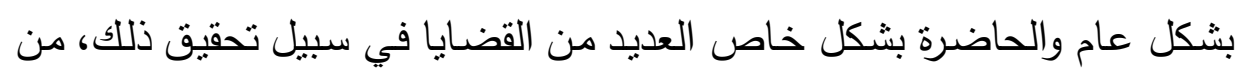

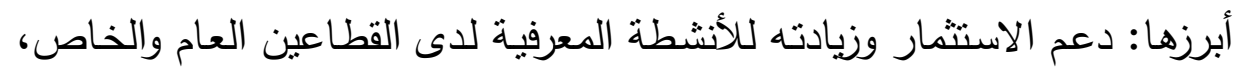

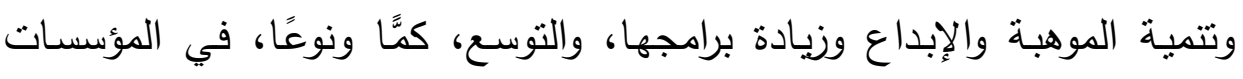

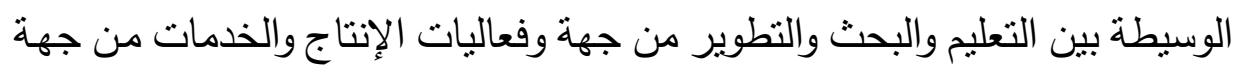
أخرى، وتعزيز مشاركة القطاع الخاص في نقل المعرفة وتوطينها ونشرها واستثمارها. تحتضن حاضرة الدمام ثلاث جامعات والعديد من المراكز البحثية ومراكز

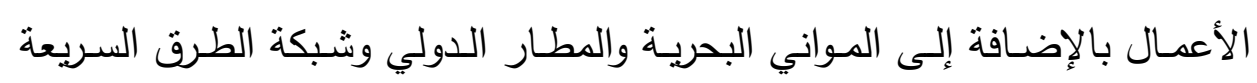

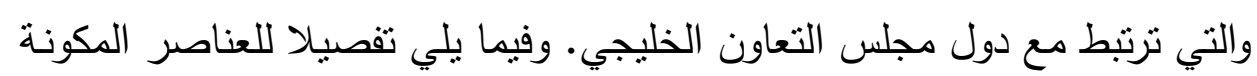

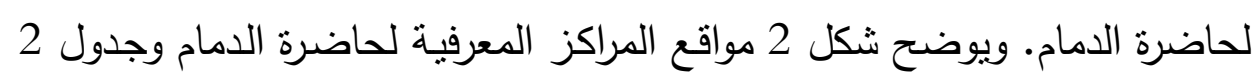
يوضح المكون المعرفي لحاضرة الدمام. 

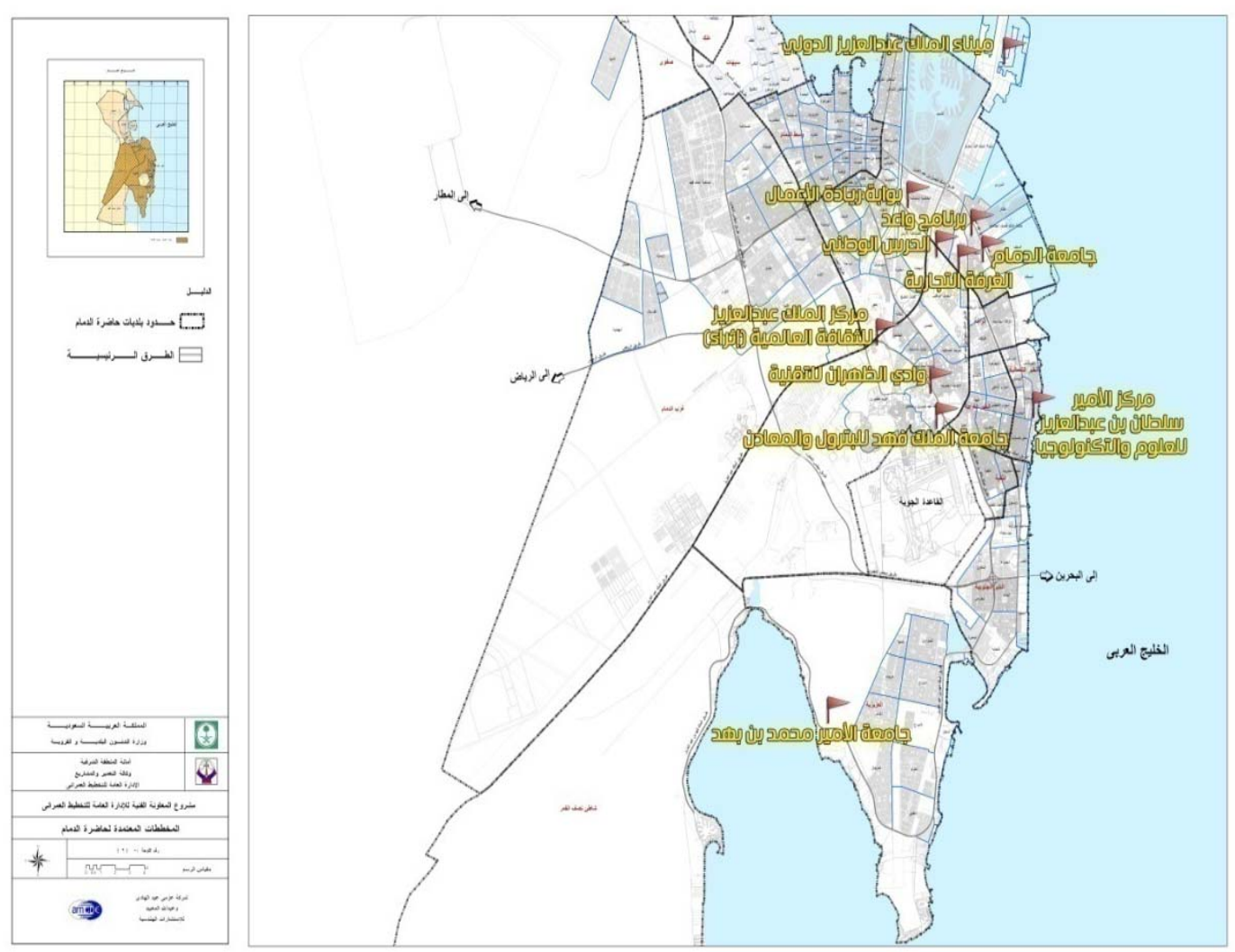

\section{شكل 2. مواقع المراكز المعرفية لحاضرة الامام.}

المصدر : وزارة الثئون البلدية والقروية-وكالة الوزارة لتخطيط الددن، (2007).

$$
\text { 7-1-1 جامعة الملك فهز للبترول والمعادن }
$$

تأسست رسميا جامعـة الملك فهد للبترول والمعادن بموجب مرسوم ملكي في 1383 هـ (1963م). ومنـذ ذلـك الوقت نمـت نسـبة الالتحساق بالجامعـة إلـى المسـتوى الـذي يتجـاوز 8000 طالب بحلـول هـذا العـام. ونتيجة للنمو الواسع لجامعة الملك فهد فقد تم منح 18563 شهادة بما في ذللك 1821 درجة ماجستير و 86 درجة دكتوراة بحلول نهاية السنة الدراسية

$$
\text { •2005/2004 }
$$


جدول 2. يوضح المكون المعرفي لحاضرة الدمام.

\begin{tabular}{|c|c|c|c|c|}
\hline الموقع & الاور او الوظيفة & الموقع الاككترونى & المساهمين & مراكز المعرفة \\
\hline الرئيسى & تركز رسالة الجامعة التعليم والبحث & $\begin{array}{l}\text { http://www.kfup } \\
\text { m.edu.sa }\end{array}$ & وزارة التعليم العالي & للبترول والمعادن الملك فهد \\
\hline المائيسى & تركز رسالة الجامعة التعليم والبحث & $\begin{array}{l}\text { http://www.ud.ed } \\
\text { u.sa }\end{array}$ & وزارة التعليم العالي & جامعة الدمام \\
\hline الرئيسي & تركز رسالة الجامعة التعليم والبحث & $\begin{array}{l}\text { http://www.pmu. } \\
\text { edu.sa }\end{array}$ & وزارة التعليج العالي & 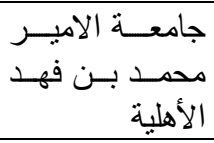 \\
\hline مدينة & نشر المعرفة الثقافية & $\begin{array}{l}\text { http://en.kingabdu } \\
\text { lazizcenter.com/ab } \\
\text { out-the- } \\
\text { center/mission/ }\end{array}$ & أرامكو السعودية & 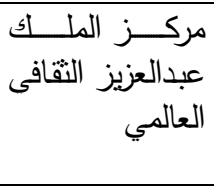 \\
\hline فرع مدينة & إنمائية لتمويل المختيلة المشيع & $\begin{array}{l}\text { http://www.riyada } \\
\text { h.com.sa } \\
\text { http://www.scsb.g } \\
\text { ov.sa }\end{array}$ & 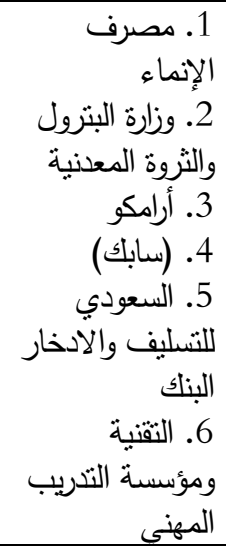 & 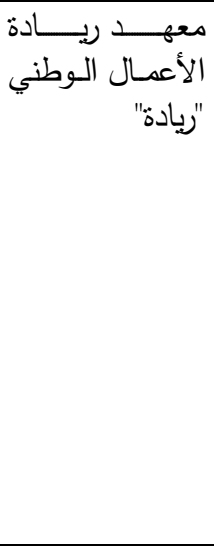 \\
\hline الرئيسي & مؤسسات مختلطة & $\begin{array}{l}\text { http://www.cham } \\
\text { ber.org.sa }\end{array}$ & للغنطقة التشارية & 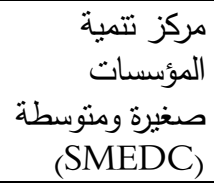 \\
\hline الخئيسي & جامعة الملك فهذ & http://scitech.sa & نشر المعرفة & 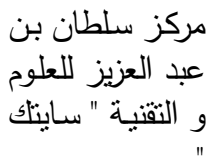 \\
\hline فرعام & موإنساتية لتمويل المشتاريع & $\begin{array}{l}\text { http://www.babriz } \\
\text { qjameel.com }\end{array}$ & شركة عبد اللطيف & باب رزق جميل \\
\hline
\end{tabular}


مدن المعرفة: دراسة حالة حاضرة الدمام - المملكة العربية السعودية

\begin{tabular}{|c|c|c|c|c|}
\hline الظئيسي & 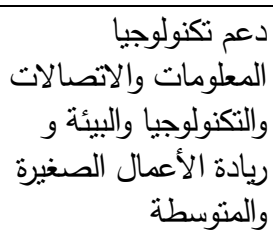 & $\begin{array}{l}\text { http://www.waed. } \\
\text { net }\end{array}$ & أرمكو السعودية & 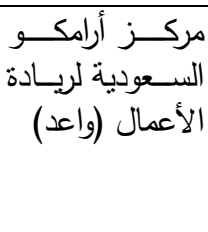 \\
\hline الزئيسي & مركز البحث والتطوير & $\begin{array}{l}\text { http://dtv.kfupm.e } \\
\text { du.sa }\end{array}$ & للبترول والمعة الملك فهن & للتقنية ادية الظهران \\
\hline الرئيسي & 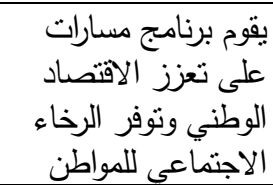 & www.scsb.gov.sa & الحكومة & 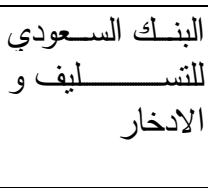 \\
\hline
\end{tabular}

ويـرتبط النمـو السـريع لجامعـة الملـك فهـ مـع التتميـة الاقتصـادية

والتقنية السريعة في المملكة. تشكل الموارد الضخمة للبترول والمعادن في المملكة تحديا معقدا ومثيرا للتعليم العلمي والإداري والتقني لمواجهة هذا التحـدي، فقد اعتمـدت الجامعـة التـدريب المتقـدم فـي مجـالات العلـوم والهندسـة والإدارة وجعلتهـا مـن أهـدافها مـن أجـل تعزيـز القيـادة وتقديم الخدمـة في مجـال الصـناعات المعدنيـة والبتروليـة في المملكة. إن القدرة على المنافسـة العالميـة لخريجي الجامعة يتطلب إعدادهم ليمتلكوا معارف متعددة، ومهارات عاليـة، وقدرة قياديـة. أمـا التميز في الأبحـاث العلميـة المعاصـرة في كافـة مجـالات الجامعـة فسـتمكنها مـن إحـداث أثر علمسي ملموس، ومن الإسهام في تلبية الاحتباجات الوطنية.

تركز الرسـالة الجامعيـة على التعليم والبحث وخدمـة المجتمع والتي تسـى إلى المحافظة على الريـادة في مجالات العلـوم والهزدسـة والإدارة. وتؤكد الجامعة بأن نتاجها البحثي يتصف بالإبداع والابتكار . ففي حين تواكب الجامعة التطورات البحثية العالمية، فإنها تولي اهتماماً بالمتطلبات الوطنية. كما أن الجامعة تنظر إلى التواصدل مع المجتمع للشراكة مع ذوي 
العلاقة، والإسهام في ازدهار المجتمع ونمائه، والإثراء لخبرات منسوبي

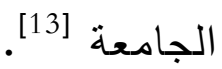
2-1-7 - 2-1 جامعة الدمام نشأت جامعة الدمام باصدار المرسوم الملكي في 1430هـ (2009م) بفصل

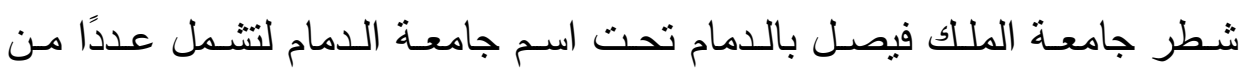

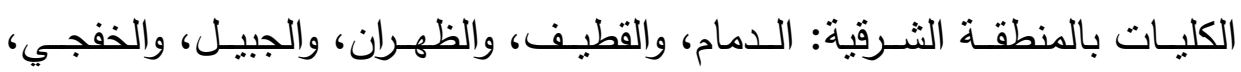

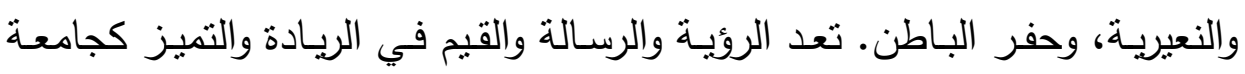

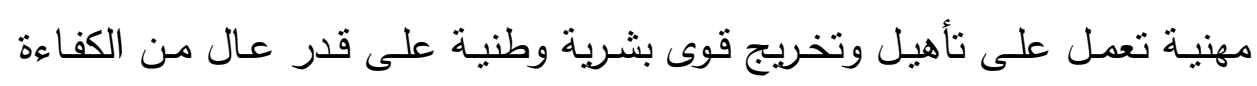

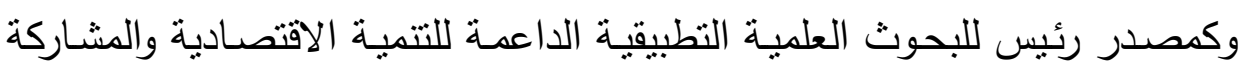

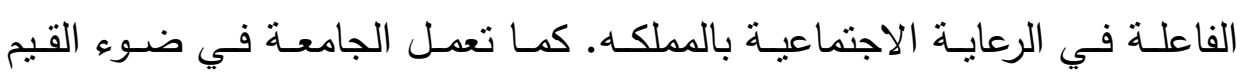

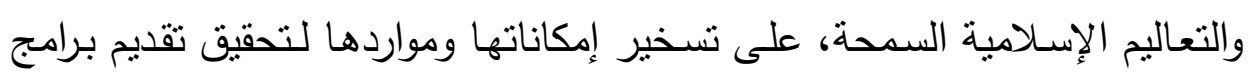

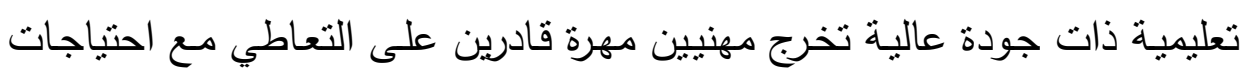

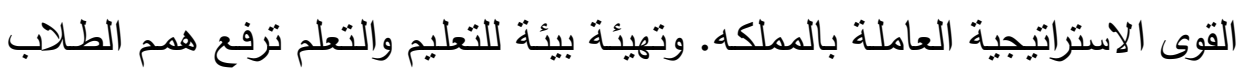

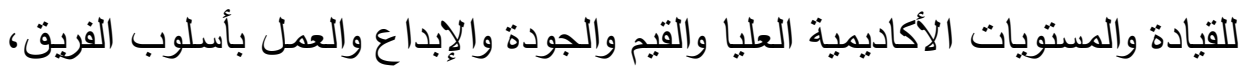

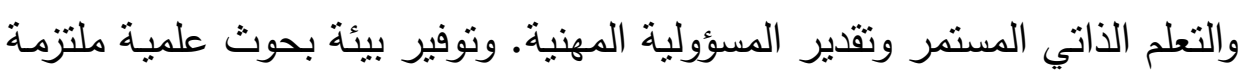

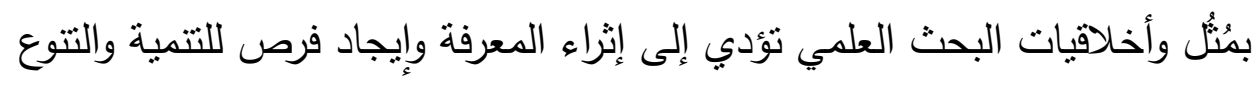
الاقتصادي • وتهيئة الخريجين لسوق العمل ليكونو شريكا فعالا في نمو الاقتصاد.

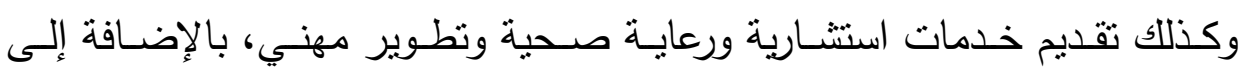

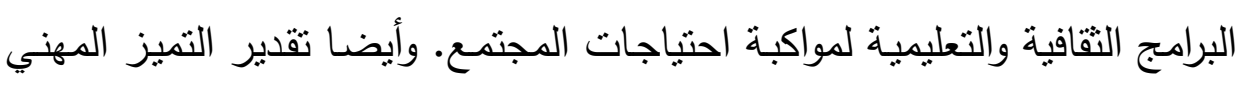

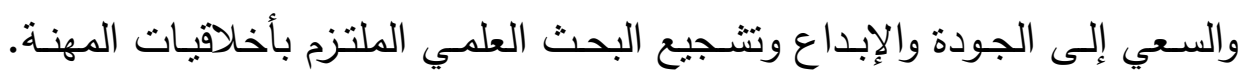

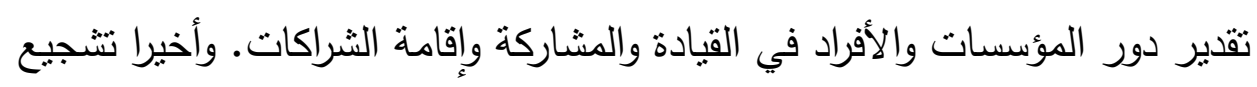
العمل الجماعي وتبادل المعارف والخبرات [14]. 


$$
\text { 7-1-7 جامعة الأمبر محد بن فهـ الأهلية }
$$

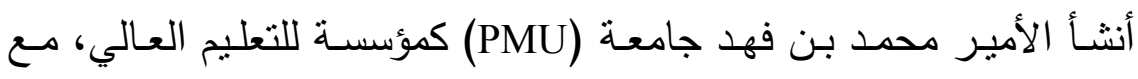
نهجها المتحور حول نقل التعليم للطالب بدرجة عالية من الابتكار ، والتي تقدم فرصة للطلاب لاستكثاف مسارات حقيقية للتعلم والابتكار أثناء إعدادهم لدورهم الابحم في المستقبل كمهنيين. تركز جامعة (PMU) على اهتمامات واحتياجات وقدرات

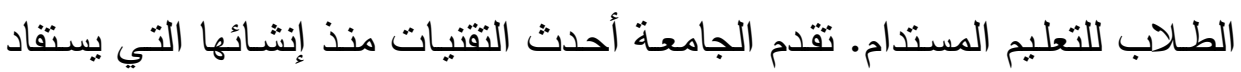
منهـا في منهجيـة التعليم وتطـوير المنـاهج الدراسـية. أعدت جامعــة (PMU) تكنولوجيـات متقدمـة مثل لوحـات ذكيـة، البـث المباشـر عبر شـبكات التلفزيـون ومؤتمرات الفيديو التي هي ذات فائدة للطلاب للحصول على تسجيل في المقررات

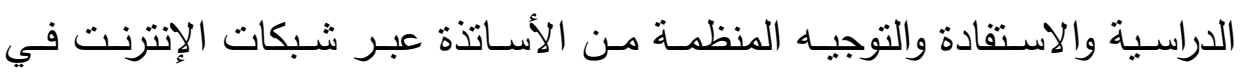
خصوصية المنازل. تلعب جامعة (PMU) دورا محوريا في توجيه المجتمع الطلابي الإني

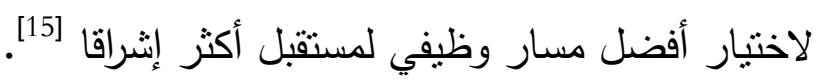
7-1-7 مركز الملك عبدالعزيز الثقافي العالمي

المركز بمبادرة مـن أرامكو السعودية، فهو صـرٌّ لإثراء المعرفـة وإطـلاق

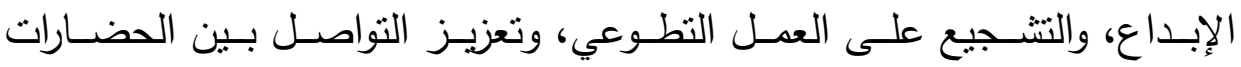

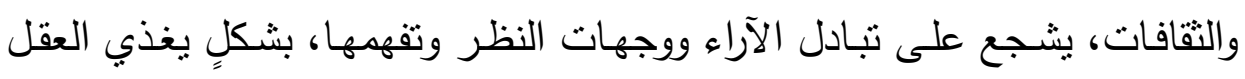

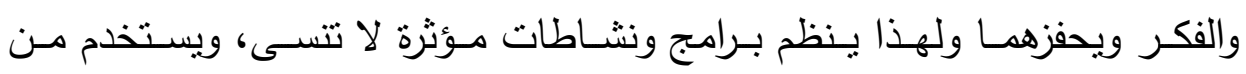

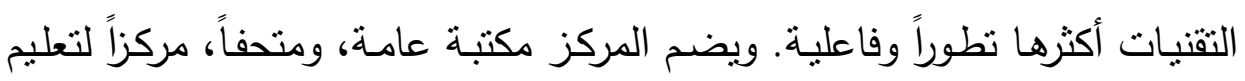

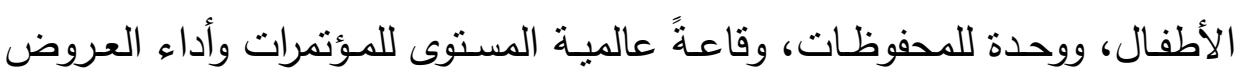
الفنية. ويعمل المركز ليكون منارة للتنمية الاجتماعية والتتوير النقافي في البلاد. المركز منتدى تفاعلي يرحب بكل الباحثين عن التجارب الفريدة والأجواء العلمية

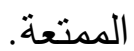


يقع مركز الملك عبدالعزيز التقافي العالمي فوق التكوين الجيولوجي الذي الذي

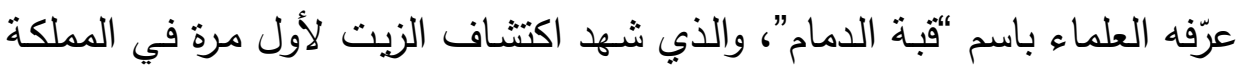

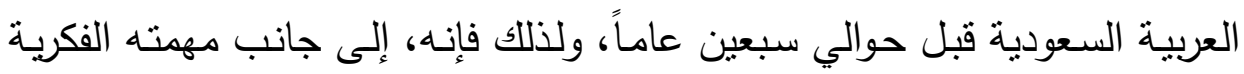

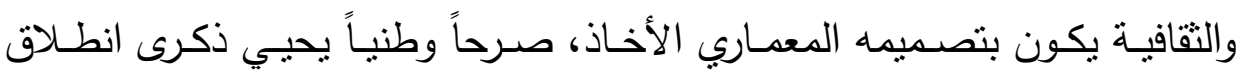

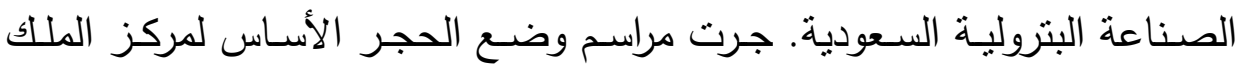

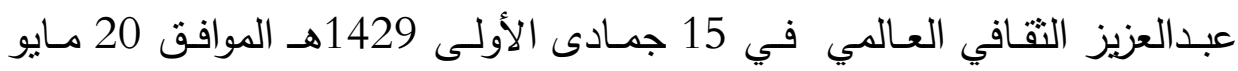

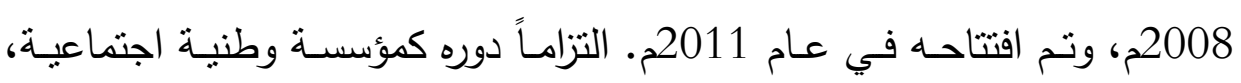

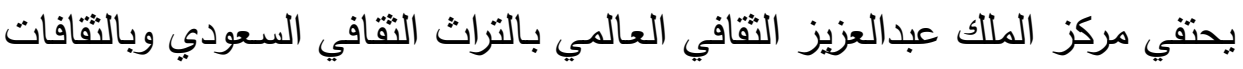
العالمبة الأخرى على حذّ سواء. يقدم المركز برنامجاً حافلاً بمختلف النشاطات على مدار السنة، بدءاً من

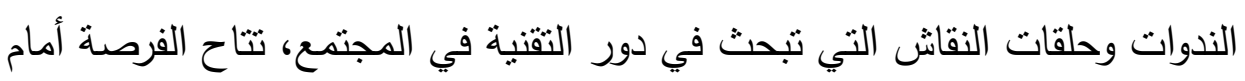
كبـرى المؤسسـات والثــركات الوطنيـة لاستضــافة الــؤتمرات الوطنيـة والعالميـة

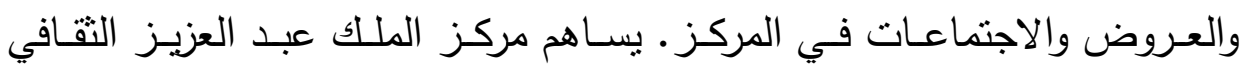
العالمي في تعزيز دور المملكة الفاعل على ساحة الأعمال العالمية [16]. 7-1-7 معهد ريادة الأعمال الوطني "ريادة" المعهد تتظيم وطني مؤسسي مستقل غير ربحي أُسس بمبادرة من وزارة

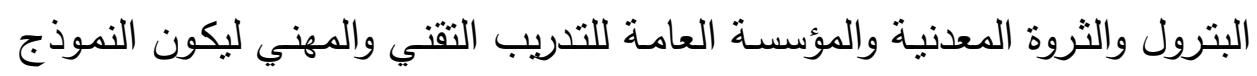
الوطني لريادة الأعمال وتتمية المنشات الصغيرة والمتوسطة الأميز محلياً وإقليميا.

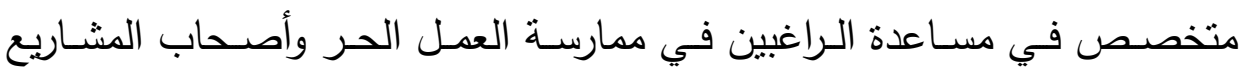
الصغيرة والمتوسطة من الجنسين من خلال التدريب والتأهيل وتقديم الاستشارات

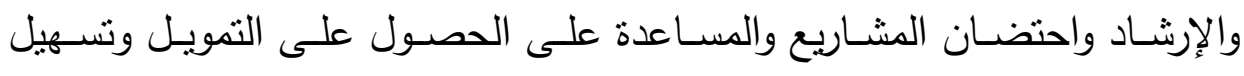
الإجراءات الحكوميـة بواسطة نخبة من المتخصصين وباعتمـاد أحدث الأسـاليب 
والتقنيات لتقديم النموذج الأميز محلياً وإقليميا في ريادة الأعمال ودعم المشـاريع الصغيرة والمتوسطة.

ويهدف المعهد إلى نشر ثقافة العمل الحر بين أفراد المجتمع وبناء سلوك إيجابي نحو ممارسته، وتطوير برنامج وطني لربادة الأعمال وتتمية المشروعات الصـغيرة والمتوسطة، وتأهيل كوادر بشرية متخصصسة في مجال ريـادة الأعمال وتتمية المشروعات الصغيرة والمتوسطة، وتأسيس مشروعات صغيرة ومتوسطة من خلال مراكز معتمدة، وتمكين رواد الأعمال والمختصين من مسايرة المستجدات في مجال ريادة الأعمال والعمل الحر.

وقد ساهم في التأسيس مجموعةٌ سداسية قوية ممثلة في شركة الصناعات الأساسية (سـابك)، شركة أرامكو السعودية، شركة الاتصالات السعودية، مصرف

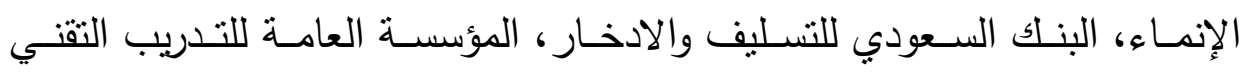
والمهنـي. حرص " ريـادة " على بنـاء الثـراكات الفعالـة مـع الجهات والمنظمـات والهيئات المحليـة التي تمتلك الخبـرة في مجـال دعم وتتميـة المنشـآت الصـغيرة والمتوسطة والتي لديها الرغبة الجادة والإمكانات التي تسهم في بناء تعاون [17]. 7-6-6 مركز سلطان بن عبد العزبز للعلوم و التقنبة " ساينك " مركز سلطان بن عبد العزيز للعلوم والتقنية "سايتك" إنشاء في عام 2000م

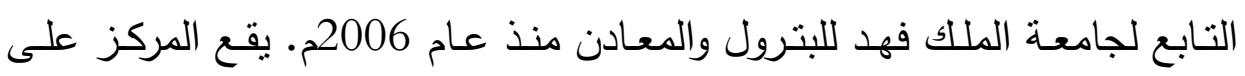
كورنيش مدينة الخبر صمم ونفذ على غرار أحدث المراكز العلمية ويشتمل على (7) قاعات عرض رئيسية تتناول مختلف العلوم والتقنية، تضم أكثر من (350) معروضة علمية، والقبة العلمية" IMAX "، المرصد الفلكي، الوحدة التعليمية، قاعة المؤتمرات، قاعة المعارض المؤقتة، مرافق إدارية وخدمات. يهدف المركز بصورة أساسية إلى تثقيف أفراد المجتمـع- خاصـة الناشئة - بمبادئ العلوم وتطبيقاتها 
وشرحها وتبسبطها من خـلال عرضها بأسلوب تفاعلي شيق يعتمد على التعليم بالترفيه/ التعليم بالتجربة والمشاهدة.

يهدف المركز لنشر مبادئ العلوم وإبداعات التقنية عن طريق عرضها بأساليب

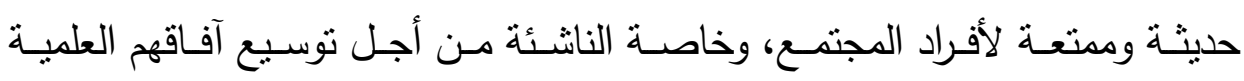

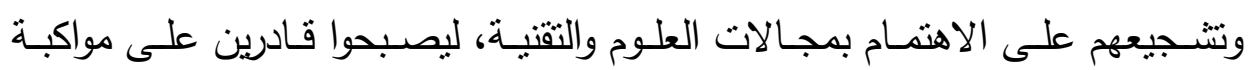

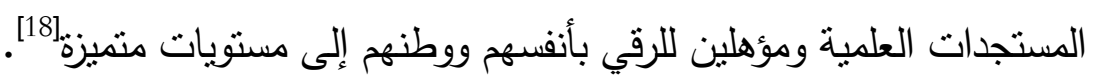
7-1-7 باب رنق جيل

باب رزق جميل هو أحد مبادرات عبداللطيف جميل الاجتماعية وهو إمتداد

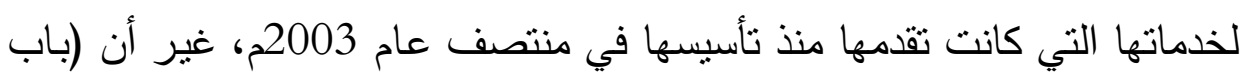

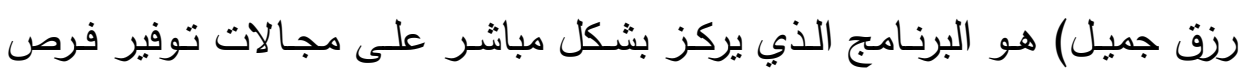

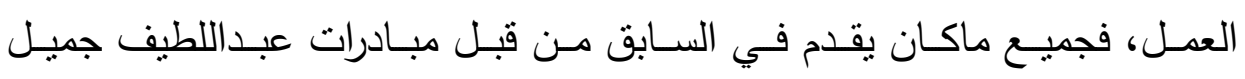

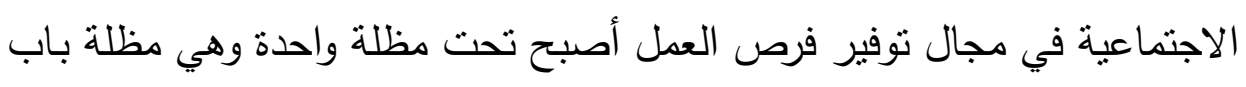

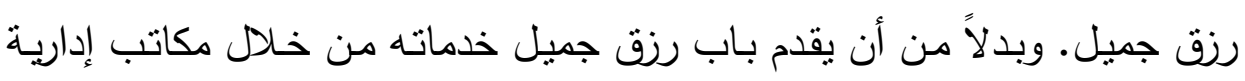

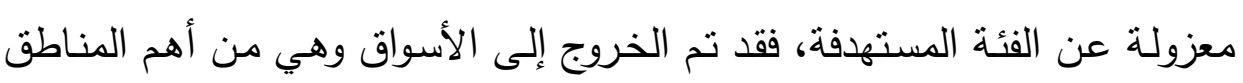

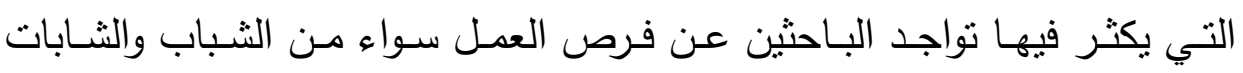

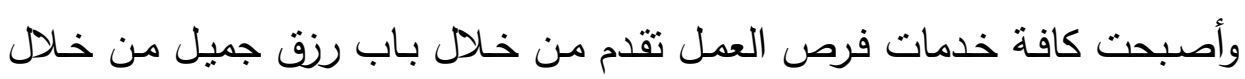

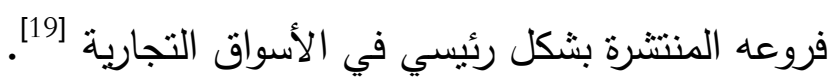
7-1-8 مركز أرامكو السعودية لريادة الأعدال (واعد)

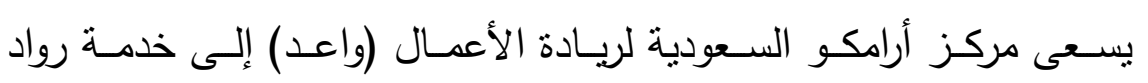

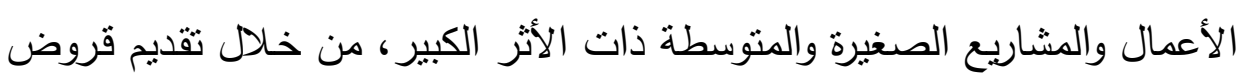

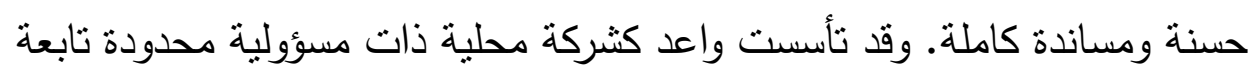

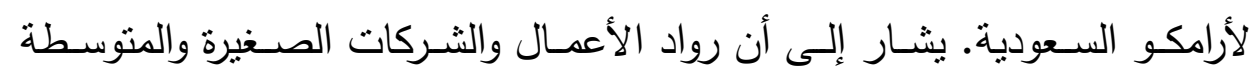


يسهمون في توفير الوظائف ويمنلون مصدراً رئيساً للتوظيف، كما يضطلعون بدور

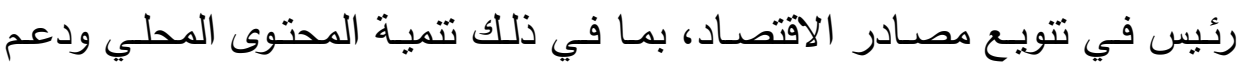

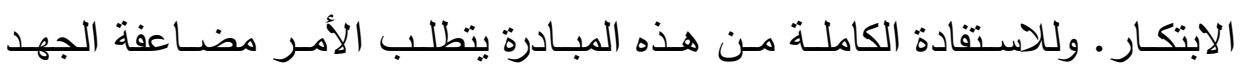

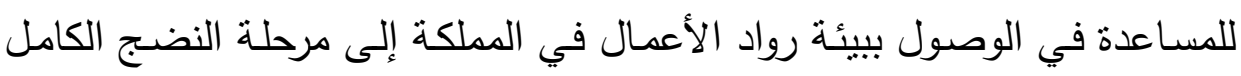
بأبعادها الهيكلية والنقافية.

مركز أرامكو السعودية لريادة الأعمال المحدودة (واعد) هي شركة ذات

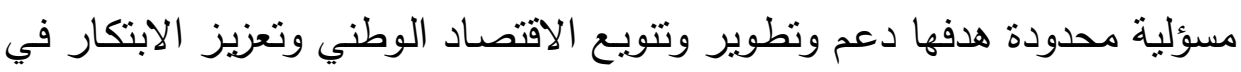

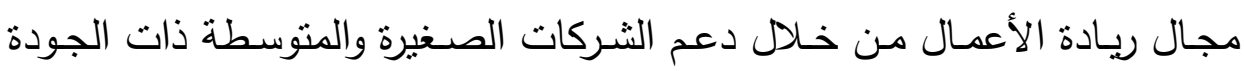
العالية ومن ثم توفير وظائف حيوية لخريجي الجامعات والكليات التقنية]

\section{7-1-7 وادي الظهلان للتقنية}

يقدم الوادي عددًا من بيئات الأعمال التي تلاهم الأثخاص على التفوق

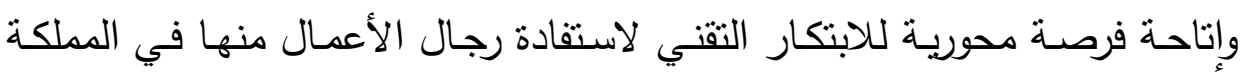

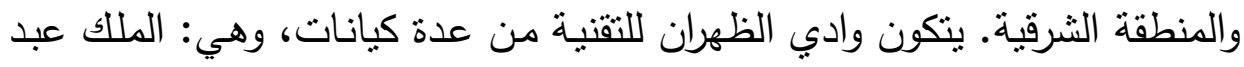

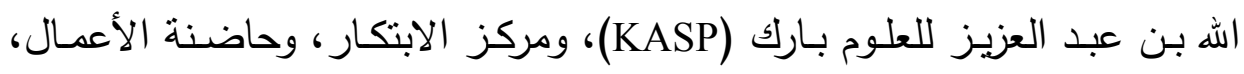

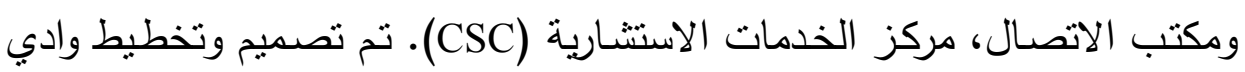

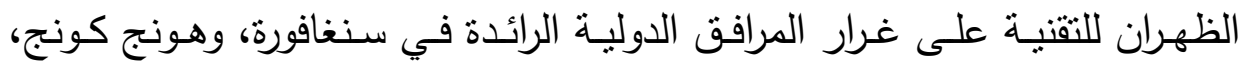

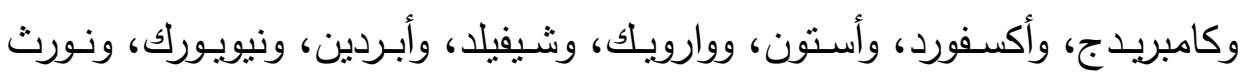

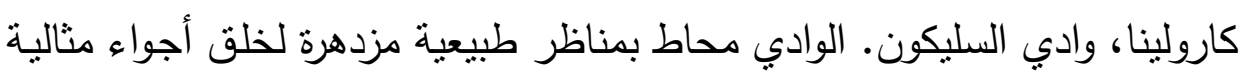

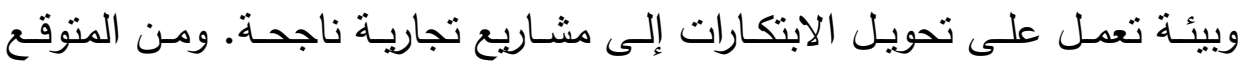

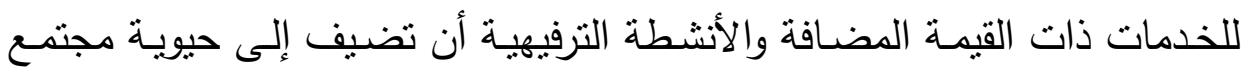

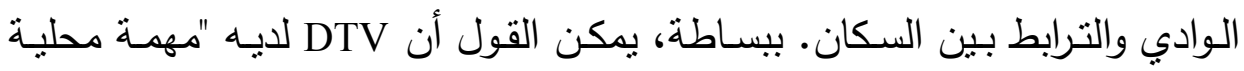

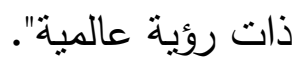


الأهداف الرئيسية من وادي الظهران للتنقية، هي: نسويق البحوث، سواء من حيث سعي الجامعة نحو مجالات مجدية تجاريا من الدراسة، وكذللك التقليل

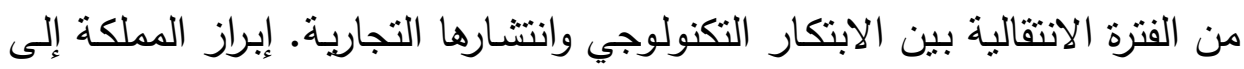

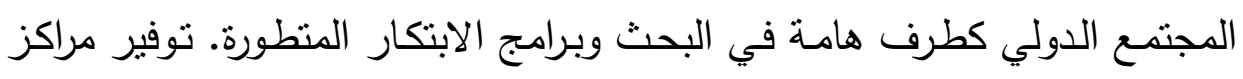

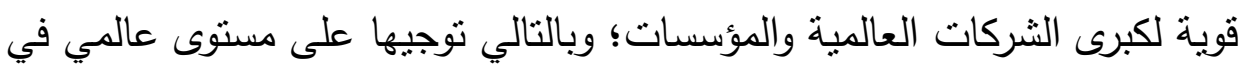

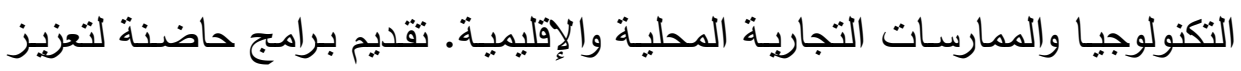
الثركات الصغيرة الناشئة والمؤسسات التي تشتد الحاجة إليها من التقنية والإدارة الماليـة. توفير فرص التوظيف للطـلاب خـلال دراستهم وبعد التخرج، وبالتـالي

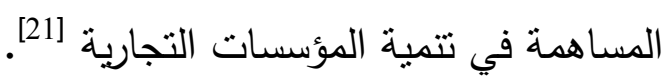
7-10-10 البنك السعودي للتسليف والادخار

صـم البنك السـودي للتسليف والادخـار برنـامج مسـارات ليكون الذراع

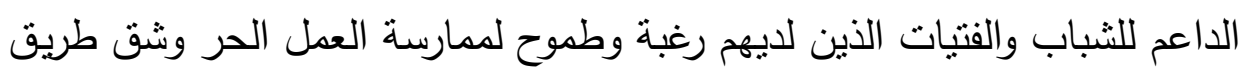

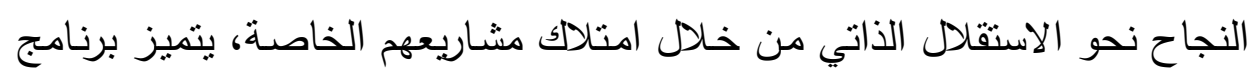

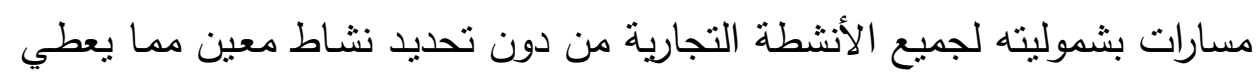

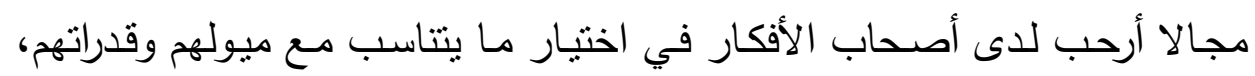

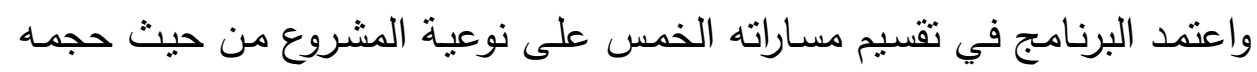

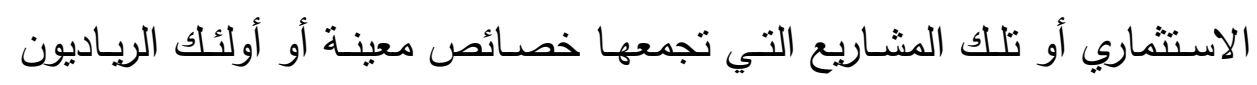
الذين تجمعهم سمات منشابهة.

يقوم برنـامج مسـارات على عدد من الأهداف التي مـن شـأنها أن تعزز الاقتصاد الوطني وتوفر الرخاء الاجتماعي للوطن والمواطن، وهي كالتالي [22]: تشجيع المواطنين المؤهلين للعمل بأنفسهم في منشأتهم. المساهمة في توفير فرص العمل للمواطنين. 
المساهمة في تعزيز دور المنشأت الصغيرة والناشئة في الاقتصاد الوطني.

$$
\text { تشجيع النشاط الاقتصادي في المناطق الأقل نموا. }
$$

الاسـتفادة مـن الميـزات النسـبية المتـوفرة فـي المنطقـة التـي ينشـأ فيهـا

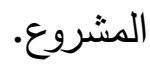

$$
\text { 7.1.11 غرفة الشرقية }
$$

أنشئت غرفة الشرقية في عام 1372هـ (1952م). وقد خطت منذ تأسيسها

وإلى الآن، خطوات واسـعة على مختلف الأصـعدة، ابتداء مـن رعايتها لمصـالح أعضائها، واهتمامها المستمر بتطوير خدماتها لمشتركيها من رجال الأعمال، إلى الى إسـهامها في تطوير اقتصـاديات المنطقـة الثـرقية، ومبادراتها المتميزة في خدمـة الاقتصـاد والمجتمع في المملكة، مرورا بتطورها هي ذاتها إداريا وتتظيميا وماليا، وانفتاحها الـدائم على المستبدات في المنظمات المماتلــة في العـالم، واستيعابها لأحدث النظم والتقنيات في بيئة خدمات قطاع الأعمال، ورعايـة مصسالح رجال الأعمال، حيث شـهدت الغرفة العديد من التطورات والتوسعات، على المستوبين "الأفقي" و "الرأسي"، مما جعلها تحتل مكانـة بارزة بين الغرف التجارية الصناعية على المسـتيين العربـي والإقليمي. مبنـى الغرفـة أقبم ليكـون معلمـا مـن معـالم المنطقة الثرقية، حيث يمثل تحفة هندسية ومعمارية وجمالية في المنطقة، بطوابقه الأربعة التي تضم ـ إضافة إلى مكاتب الإدارات والأقسام المختلفة ـ قاعات عديدة فخمة وأنيقة للمؤتمرات الدولية والمحلية والندوات والاجتماعات والمعارض. وتوسـت "الغرفـة" أفقيـا، وبدلا من مبنى واحد يتمثل في المقر الرئيسي بالـمام، امتدت إلى مختلف محافظـات المنطقة الثـرقية، لتقدم خدماتها لرجـال الأعمال في فروعها بالجبيل والخفجي والقطيف. ورأسيا لا تتوقف غرفة الشرقية عن التطور ، وعلى هذا الصعيد،شهدت الغرفـة العديد مـن مظـاهر وصـور هذا 
النطور، على سبيل المثال: إنشاء مركز تتمية المنشآت الصغيرة والمنوسطة، مركز

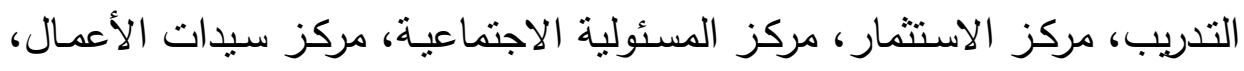

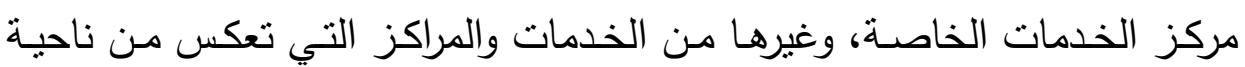
توجهات الغرفة واهتماماتها في خدمة الوطن والمنطقة، وتعكس من ناحية أخرى الخي حرصها على تبني قضايا بعينها تؤكد رؤيتها المستقبلية [23].

\section{7-2 تحليل الفرص والثعوائق (SWOT Analysis)}

ينطلب التوجه نحو الاقتصاد القائم على المعرفة تعزيز اهتمام المواطن

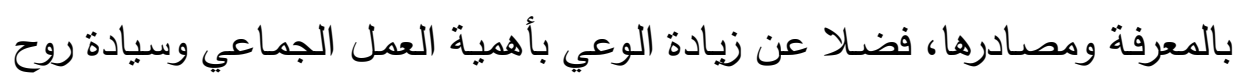

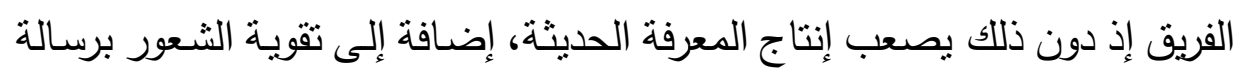

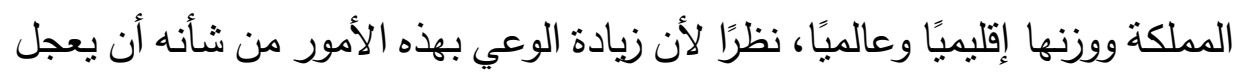

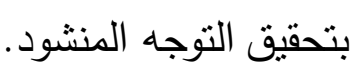

تم تطبيق منهج التحليل الرباعي SWOT analysis على الحالة الدراسية

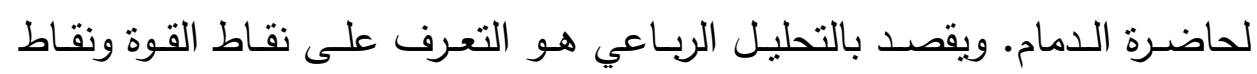
الضعف في البيئة الداخلية لحاضرة الدمام وكذلك تحديد الفرص والتهديدات عن التهات

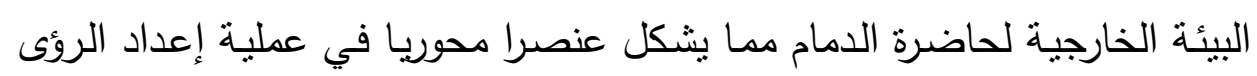

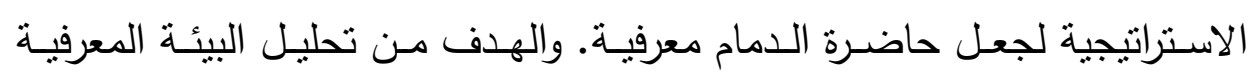
لحاضرة الدمام باستخدام التحليل الرباعي هو بناء الرؤى المستقبلية والتي تعتمد

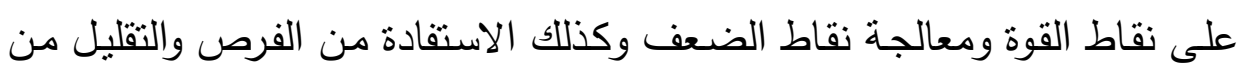
أثر التهديدات. يتم ذلك من خلاطل تحليل محاور مصفوفة التحليل الرباعي وهي

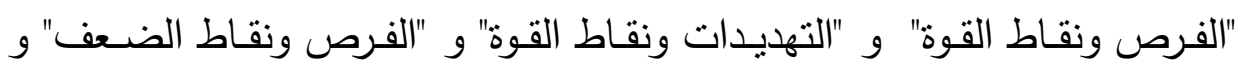
"التهديدات ونقاط الضعف" (جدول 3). 
جدول 3. التحليل الرياعي SWOT analysis.

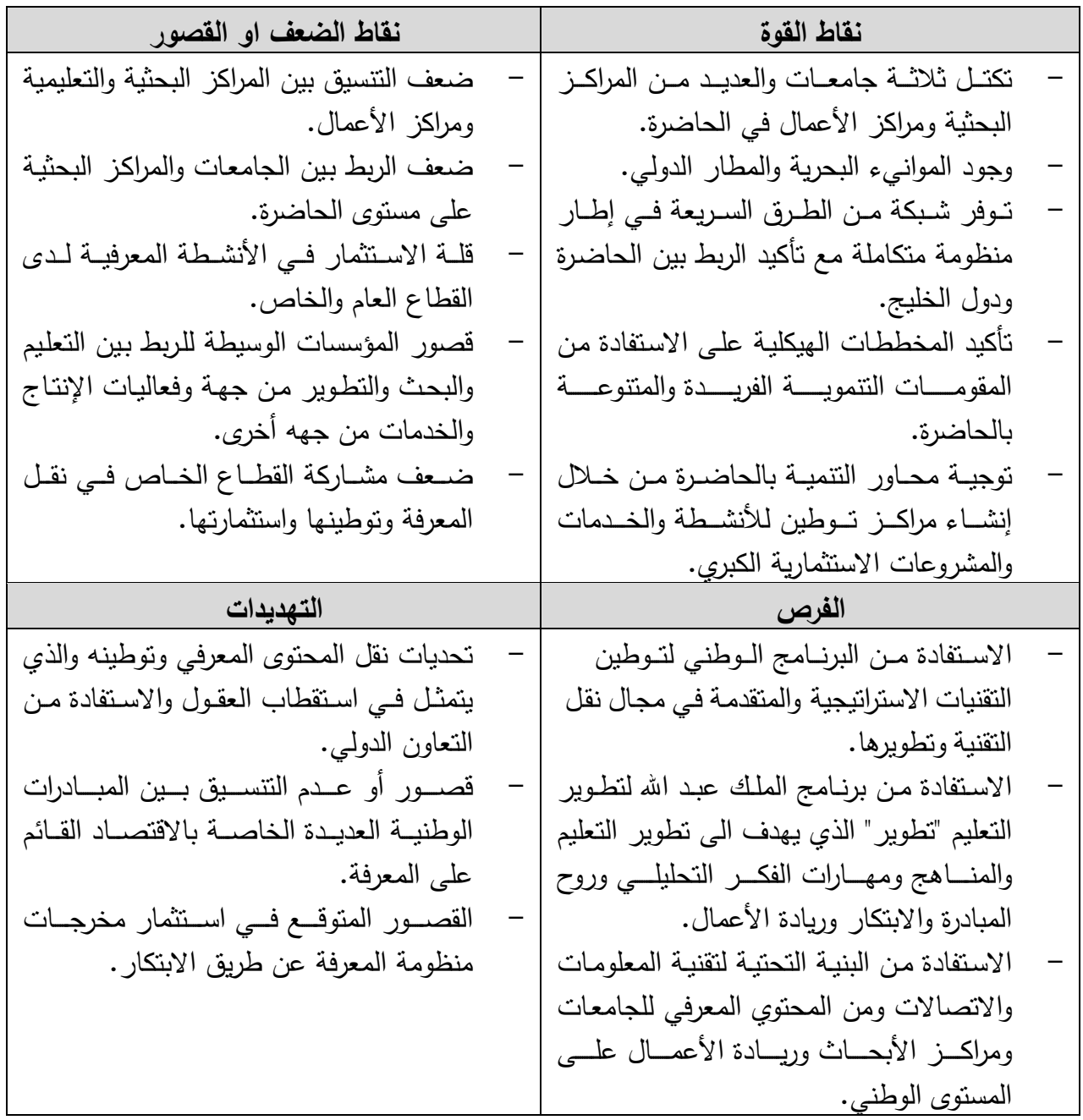

وبتحليـل محسور الأول "الفرص ونقـاط القوة" نجـد أن إمكانـات ومقومـات الحاضرة تكمن فيما يتوفر من البنية التحنية لتقنية المعلومات والاتصالات وكذلك

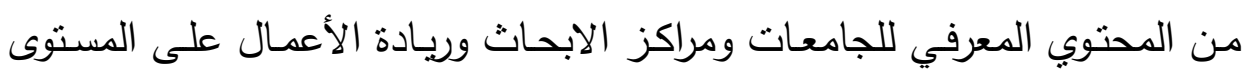

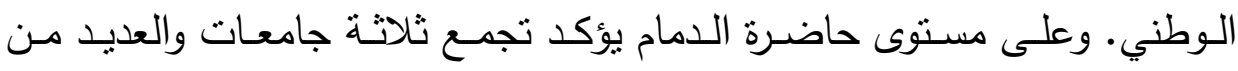

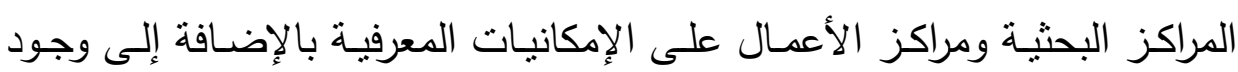
الموانيء البحربـة والمطار الدولي مـع توفر شبكة من الطرق السريعة في إطـار 
منظومة متكاملة مع دول الخليج. الأمر الذي تأكد من خلال المخططات الهيكلية

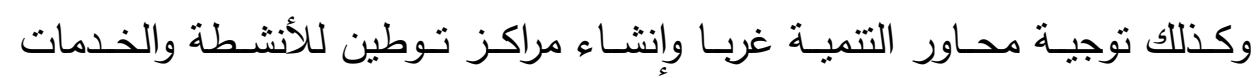
والمشروعات الاستثمارية الكبري عليها.

وبتحليل المحور الثاني "التهديدات ونقاط القوة" تم رصد تحديات نقل المحتوى المعرفي وتوطينه على المستوى الوطني والذي يتمتل في استقطاب العقول والاستفادة من التعاون الدولي، كذللك قصور التتسيق بين المبادرات الوطنية العديدة

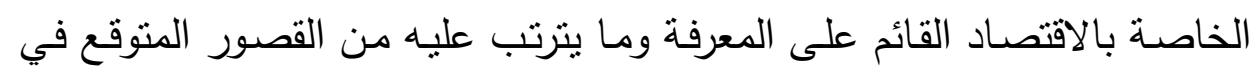

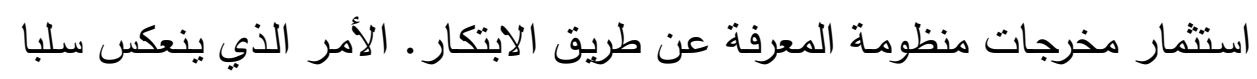

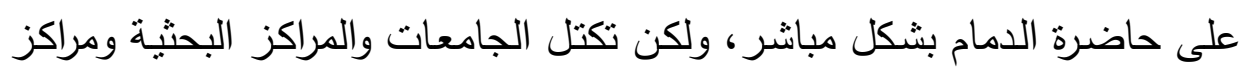

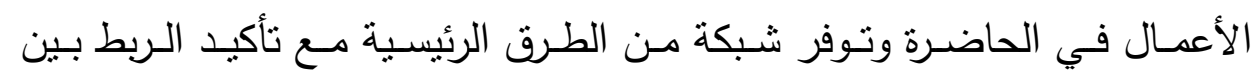

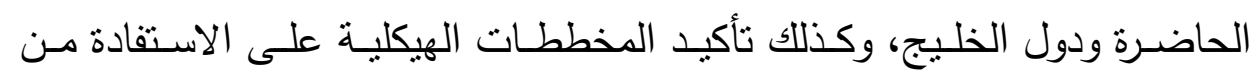

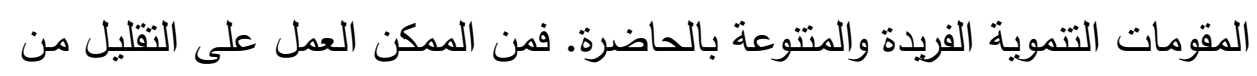

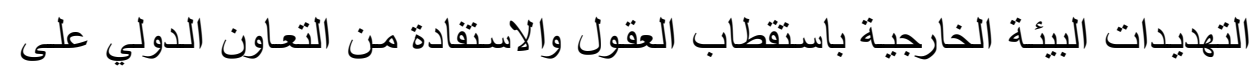
مستوى الحاضرة للاستفادة من نقاط القوة التي تقع في رحاب الحاضرة. وبتحليل الدحور الثالث "الفرص ونقاط الضعف" ويعمل هذا المحور على

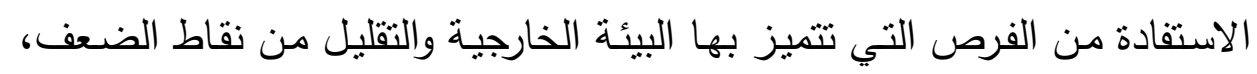

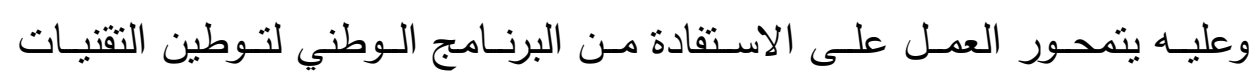

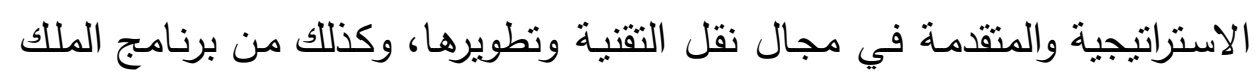

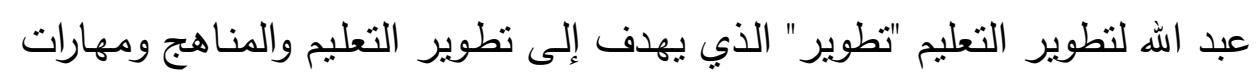

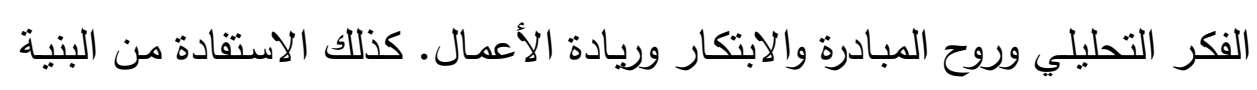
التحتية لتقنية المعلومات والاتصـالات ومن المحتوى المعرفي للجامعات ومراكز

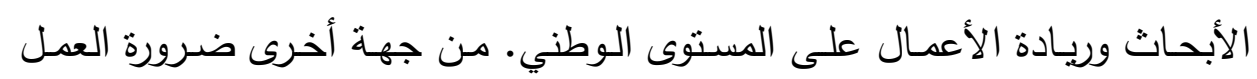

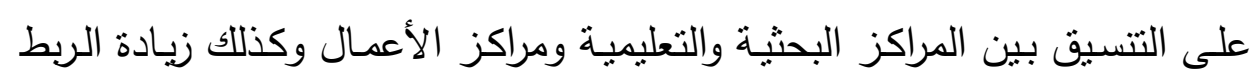


بـين الجامعـات والمراكـز البحثيـة على مسـتوى الحاضـرة، مدـا يـؤدي إلـى رفـع الاستثمار في الأنثطة المعرفية لدى القطاع العام والخاص، واجتذاب المؤسسات الوسيطة للربط بين التعليم والبحث والتطوير وبين فعاليات الإنتاج والخدمات، وبذلك تزيد مشاركة القطاع الخاص في نقل المعرفة وتوطينها واستثارتها. وبتحليل المحور الرابع "التهديدات ونقاط الضعف" فإن المستهذف من هذا المحور هو تجنب المخاطر والتهديدات والتخفيف من أثزها والتي قد نتتج عن نقاط الضـف. وياتي ذلك بالعمل على ومحاولة السـى إلى التحالف بين الجامعات ومراكز البحوث وريادة الأعمال داخل البيئة الداخلية لحاضرة الدمام لنقل المعرفة وتوطينها والذي يتمثل في استقطاب العقول والاستفادة من التعاون الدولي. كذلك محاولـة الاسـتفادة مـن المبـادرات الوطنيـة العديدة الخاصـة بالاقتصـاد القائم على لـى المعرفة، وعلى هذا يمكن التوقع باستثمار مخرجات منظومـة المعرفة عن طريق

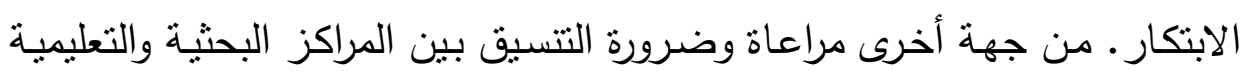
ومراكز الأعمال داخل حاضرة الدمام، مما يؤدي إلى زيادة الاستثمار في الأنشطة المعرفية لدى القطاع العام والخاص، وظهور المؤسسات الوسيطة للربط بين التعليم والبحث والتطوير من جهة وفعاليات الإنتاج والخدمات من جهة أخرى، وزيادة مشاركة القطاع الخاص في نقل المعرفة وتوطينها واستثماراتها. ويسـتخلص مـن مصـفوفة التحليـل الربـاعي ذات المحساور الأربعـة تعزيـز التتمية البشرية، ونشر المعرفة، وتوسيع الخيارات لأفراد المجتمع في اكتساب المعارف والمهارات والخبرات. تعزيز جهود نقل المعرفة وتوطينها في جميع القطاعات الاقتصادية والاجتماعية. وكذلك رفع مستوى قدرات الحاضرة في إنتاج

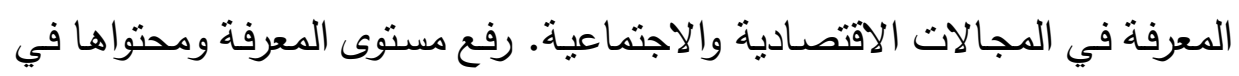
الأنشطة الإنتاجية والخدمية في القطاعين العام والخاص. وتوفير البيئة التقنية 
والإدارية والتتظيمية، فضلا عن البنية التحتية لتقنية المعلومات والاتصالات، وزيادة وعي المواطن بأهمية المعرفة، وزيادة المحتوى الرقمي العربي. اعتماد آليات تفضي إلى زيادة نشر قواعد المعرفة للتوجه نحو الاقتصاد القائم على المعرفة. العمل على زيادة قدرات الحاضرة في مجال نقل المعرفة وتوطينها. والعمل على تحقيق زيادة أنشطة توليد المعرفة، مع تطوير المحتوى المعرفي للارتقاء

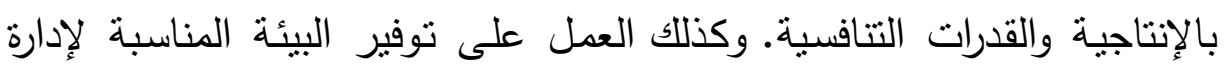
المعرفة. تحفيز القطاع الخاص للتوسع في الإنفاق على البحث والتطوير والابتكار من خلال زيادة الخريجين ذو القرات العالية في الموهبة والإبداع. 8. - النتائج والتوصيات

لعل من أبرز ما يميز الحقبة الحالية من الحضارة هو صعود دور المعرفة

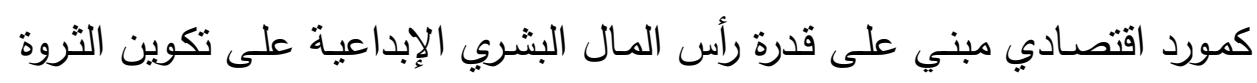

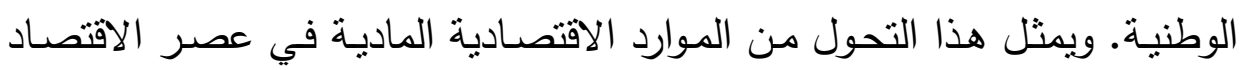

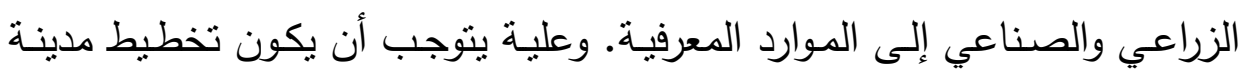
القرن 21 نموذجاً جديداً يتلائم مع مجتمع المعرفة والمعتمد على شبكات الاتصـال

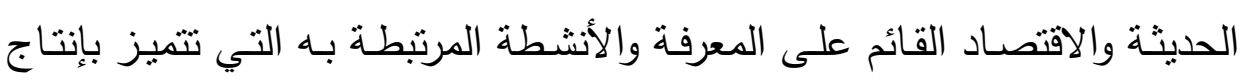

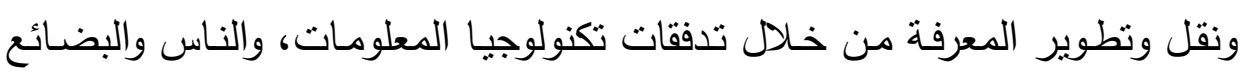

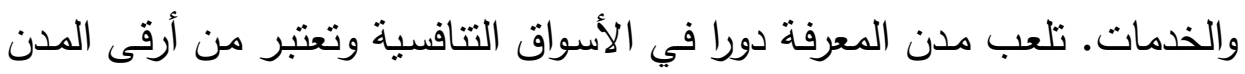

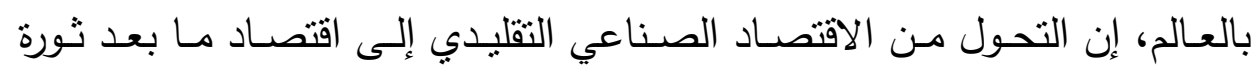

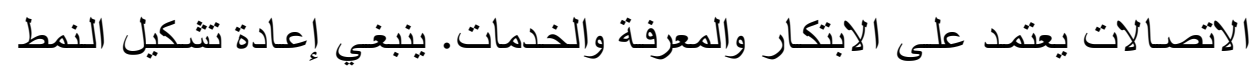

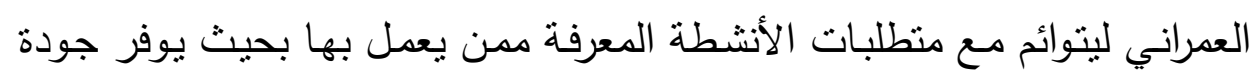

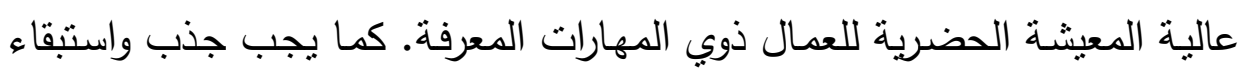

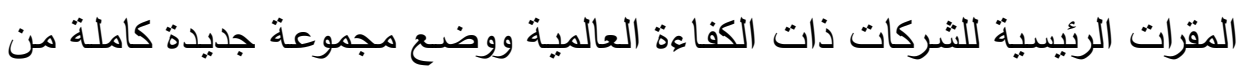

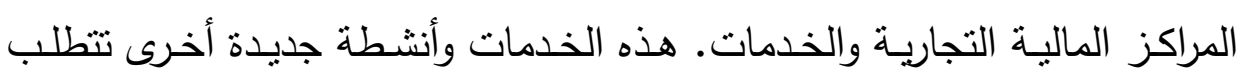


فراغـات حضـرية نشـطة مـع تـوزرع اسـتخدامات الأراضـي حسـب نمـوذج جديـــ للتخطيط مع إمكانية الوصول، حيث ظهور مفاهيم شبكة الاتصال أصبحت بدلا من القرب المادي أو التواصل الجغرافي. ينبغي ترسيخ مفاهيم المعرفة ومراكز ومناطق الابتكار وتوجيه المخططين الحضـربين في استحداث أنمـاط وأثـكال مناسبة لمدينـة العصـر المعرفـة. البنيـة التحتية المتطورة ذات التقنية العالية لثبكة اتصالات عالية السرعة هي سمة هامـة مـن سـمات هذه المدينـة المعرفيـة الجديـدة. كمـا يوضـع في الاعتبـار أن مدينـة

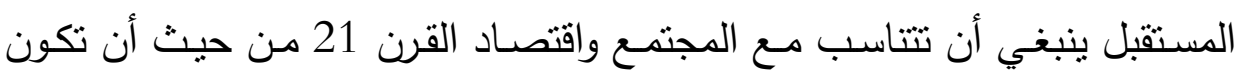
ذكيـة ومسـتدامة، ومدينـة المعرفـة لا تضـع للحدود الماديـة أهميـة. يمكن للأفـراد والجماعات والمعلومات والسلع والأفكار أن تتدفق بحرية داخل وبين المدن التي تقدم سلسلة كاملة من وسـئل التزفيـه الثقافيـة والمتعـة للمقيمين والزوار على حد سواء.

إن الانتقال من مدينة تقليديـة حديثة لن تكون كاملة إذا مـا يصـاحب ذلك تغييرات مؤسسية لتعزيز قدرات تتظيم المشاريع واكتساب المعرفة التقنية، والخبراء الدوليين والثركات المتعددة الجنسيات، وتشـيع مراكز البحث والتطوير والتتمية لاقتصادات التكتل التي تعتمد على الجامعات ومؤسسات قائمسة على التكنولوجيا، معاهد التعليم، الحدائق العلمية والثركات الخاصـة. ويجب وضـع تشريعيات جديدة

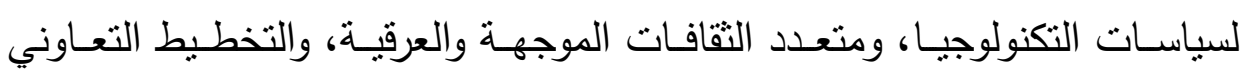
والتعلم عن بعد وصقل المهارات العاملة في المدينة. من خـلال الدراسـات والتحليل، ظهرت إمكانية وضـع حاضـرة الدمام على أنها حاضرة معرفية نتافسية. وذلك من خلال كيفية الاستفادة من الأصول المعرفية التي تمتلكها لتحقيق الانتقال الناجح من قاعدة اقتصادية تقليدية حديثة إلى قاعدة اقتصاد ما بعد ثورة المعلومات المعرفة. مع الإثارة إلى ضرورة مراعاة التحولات 
اللازمـة في تخطـيط اسـتخدام الأراضـي والثـكل الحضـري للحاضـرة. ووضـع الاستراتيجيات الحضرية لتعزيز عملية التغيير •

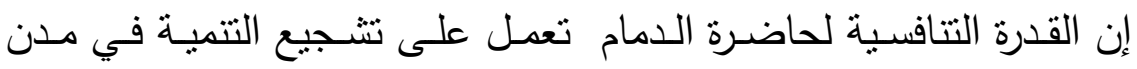

الحاضرة لتعزيز مكانتها باعتبارها مركزا المعلومات والاتصالات في الإقليم. ولا بد

من الإشـارة إلى محاولة لرسم بعض جوانب التوقعات الماديـة ذات الصلة بمدينة المعرفة كما حدث في حاضرة الدمام. وهناك حاجة إلى أبحاث وتحليلات جديدة لدراسة الآثار المترتبة على تكنولوجيا المعلومات والاتصالات على تطوير وتغيير اسـتخدام الأراضـي والثـكل الحضـري ذات الصـلة. ومجـالات أخرى مـن البحوث تركز اهتمامها على شـرح العلاقـات المعقدة بـين التركيبـة الاجتماعيـة للمدينـة، نسيجها الحضري وارتفاع الاقتصاد المعرفي. المراجع

Amidon, D.M. (2003) "The Innovation Superhighway", Butterworth-Heinemann.

Graham, S. and Marvin, S. (1996) Telecommunications and the City. Electronic Spaces, Urban Spaces (London, Routledge).

Abu-Anzeh, N. and Tahar Ledraa, T. (2007) "Planning the Knowledge City: Can it be an option for Riyadh?" The 2nd International Symposium on knowledge cities: Future of Cities in the Knowledge Economy 16-18 July 2007 - Shah Alam, Selangor, Malaysia.

Friedmann, J. (1995) where we stand: A Decade of World City Research, In: P. Knox and P. Taylor (Eds) World Cities in a World System, pp. 21-47. Cambridge: Cambridge University Press.

Healey, P. (2004) Creativity and Urban Governance, Policy Studies, 25(2): 87-102 Sandercock, L. (Ed) (1998) Making the Invisible Visible: A Multicultural Planning History, University Of Berkeley Press, Berkeley, Ca.

Dematteis, G. (1988) The Weak Metropolis, In: L. Mazza (Ed.) World Cities and the Future of the Metropolis, pp. 121-133 (Milano, Electa-Xvii Triennale).

Castells, M. (1996) The Rise of the Network Society (Oxford, Blackwell Publishers).

Bertolini, L. and Dijst, M. (2003) "Mobility Environments and Network Cities", Journal of Urban Design, 8 (1): 27-43. 
"الاقتصاد

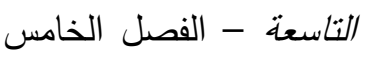

(2010) خطة التنمبية

وزارة الاقتصاد والتخطيط

\section{وزارة الثئون البلاية والقروية-وكالة الوزارة لتخطيط المدن (2007) الهخطط الإقلبهي

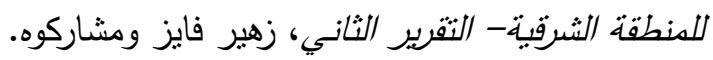

King Fahed University of Petoleum \&Minerals, http://www.kfupm.edu.sa

Bab Rizq Jameel BRJ, http://www.babrizqjameel.com 


\title{
Knowledge City: Case Study of Dammam Metropolitan - Kingdom of Saudi Arabia
}

\author{
Faez Saad Al-Shihri
}

\author{
Department of Urban and Regional Planning, College of Architecture \\ and Planning, University of Dammam, Dammam, Saudi Arabia
}

fshihri@ud.edu.sa

(Received: 9/8/2012, Accepted: 1/8/2013)

\begin{abstract}
The research attempts to investigate what a knowledge city should be and to identifiy its planning dimensions, components, requirements. The traditional city is formed according to a strategy based on the concepts of traditional economy, which depends on the resources and their distribution and relationship to the production location, where a city master plan a reperentative of areas of economic activities that depend on them. The research indicates that the method of urban planning witnessed by the city today is not consistent with the requirements of the city of tomorrow, which depends on knowledge economic and constitutes different activities where the production and use of information and knowledge became key drivers in its urban development and effective techniques that underlying its urban functions and high social lifestyles categories. The research reviews some learned lessons from the international experiences of some famous knowledge cities around the world. The research concludes with a case study of Dammam Metropolitan area in Eastren provinc of Saudi Arabia explaining the possibilities and opportunities of Dammam Metropolitan area becoming a beacon of knowledge.
\end{abstract}

Keywords: Urban Planning, Knowledge city, Eastren Province, Dammam Metropolitan, Kingdom of Saudi Arabia. 